\title{
Applications of aminocarbazoles in heterocyclic synthesis
}

\author{
P. Narayana Reddy $*^{a}$ and Pannala Padmaja $*^{b}$ \\ ${ }^{a}$ Department of Chemistry, School of Technology, Gitam University, Hyderabad-502 102, India \\ ${ }^{b}$ Department of Chemistry, JNTUH College of Engineering, Kukatpally, Hyderabad-500 085 , \\ India \\ E-mail: iictpnreddy@gmail.com; padduiict@gmail.com
}

DOI: http://dx.doi.org/10.3998/ark.5550190.p008.822

\begin{abstract}
Aminocarbazoles are versatile building blocks in organic synthesis. This review focuses on the application of aminocarbazoles to generate a large variety of fused carbazole heterocycles such as pyridocarbazoles, isomeric pyridocarbazoles, thiazolocarbazoles, pyrimidocarbazoles, pyrrolocarbazoles, indolocarbazoles, quino- and chromeno-carbazoles and many others. Many of these molecules exhibit promising biological activities.
\end{abstract}

Keywords: Aminocarbazoles, cyclization, one-pot syntheses, three component reactions, ellipticine

\section{Table of Content}

1. Introduction

2. Synthesis of Pyridocarbazoles

2.1. Pyrido[2,3-c]carbazoles

2.2. Pyrido[2,3-c] carbazol-1-ones

2.3. Hydroxypyridocarbazoles

2.4. Dihydropyridocarbazoles

3. Synthesis of Isomeric Ellipticine Derivatives

4. Synthesis of Thiazolocarbazoles

4.1. Thiazolocarbazolecarbonitriles

4.2. 2-Aminothiazolocarbazoles

5. Synthesis of Pyrimidocarbazoles

6. Synthesis of Pyrrolo- and Indolo-carbazoles

7. Synthesis of Quino- and Chromeno-carbazoles

8. Synthesis of fused Naphthyridines 
9. Synthesis of other Heterocycles

10. Conclusions

11. Acknowledgements

12. References

\section{Introduction}

Carbazole derivatives are widely utilized in medicinal, ${ }^{1-5}$ organic, ${ }^{6-7}$ and material chemistry. ${ }^{8-9}$ In particular, aminocarbazoles and its derivatives have gained much attraction due to their prominent pharmacological activities. ${ }^{10-30}$ The amino carbazole derivative has the potential of being active against Alzheimer's disease since the presence of an amino group at the indole nucleus has shown promising results as a rehabilitative medicine. ${ }^{31}$ 1-Aminocarbazoles have been identified as Bcl-2 protein inhibitors, ${ }^{32}$ NPY5 antagonists, ${ }^{33}$ and anion receptors. ${ }^{34}$ Aminocarbazoles are also useful intermediates for syntheses of various dyes and pigments, stabilizers for polymers, pesticides, photographic materials and diagnostic reagents in cytochemical studies. For example, 3-amino-9-ethylcarbazole has been widely used as a peroxidase suitable for the colorimetric detection of antibodies for the diagnosis of certain diseases. ${ }^{35-38}$ Both polymeric and molecular amorphous derivatives of 3-aminocarbazoles have attracted interest of the researchers due to their semiconductive properties. ${ }^{39-43}$ For these considerations, many synthetic approaches have been developed towards the syntheses of aminocarbazoles and their derivatives. ${ }^{44-59}$

Aryl and heteroaryl-annulated carbazoles, such as pyridocarbazoles, indolocarbazoles, and pyrrolocarbazoles have attracted growing attention since they are distributed in numerous natural products with diverse useful bioactivities. ${ }^{60-68}$ Aminocarbazoles have been an important synthon to construct pyridocarbazoles, ${ }^{69}$ which are well known for their antitumor properties. ${ }^{70,71}$ Also, aminocarbazoles have been used to prepare pyrimido $[5,4-b]$ carbazole derivatives. ${ }^{72}$ The main objective of the present survey is to provide the applications of aminocarbazoles in the synthesis of various heterocycles and provide useful and up-to-date data for organic and medicinal chemists.

\section{Synthesis of Pyridocarbazoles}

Pyridocarbazoles are important constituents of heteroannulated carbazoles and exhibit a wide spectrum of biological and medicinal activity such as treatment of breast cancer, intercalation into the DNA double helix, inhibition of topoisomerase II, and anti-HIV agent. ${ }^{73-75}$ 


\subsection{Pyrido[2,3-c]carbazoles}

Pyrido[2,3-c]-, pyrido[2,3-b]-, and pyrido[2,3-a]carbazoles were synthesized from various 3amino- and 1-aminocarbazoles via Povarov reaction with ethyl vinyl ether as the dienophile. ${ }^{76}$ This transformation is catalyzed by cerium(IV) ammonium nitrate (CAN) under mild reaction conditions without a co-catalyst or ligand. The reaction of 3-aminocarbazoles 1, ethyl vinyl ether 2 and CAN (10 mol\%) in acetonitrile proceeded smoothly gave the corresponding pyrido[2,3-c]carbazoles 3 in good yield. When the 3-aminocarbazole $\mathbf{1}$ was substituted by a methyl group at C4, a 3-amino-4-methylcarbazole, the products have the pyrido[2,3-b]carbazole skeleton 4. On the other hand, when 1-aminocarbazole 5 was subjected to the Povarov reaction under same reaction conditions pyrido[2,3-a]carbazole $\mathbf{6}$ was obtained as the product (Scheme 1).
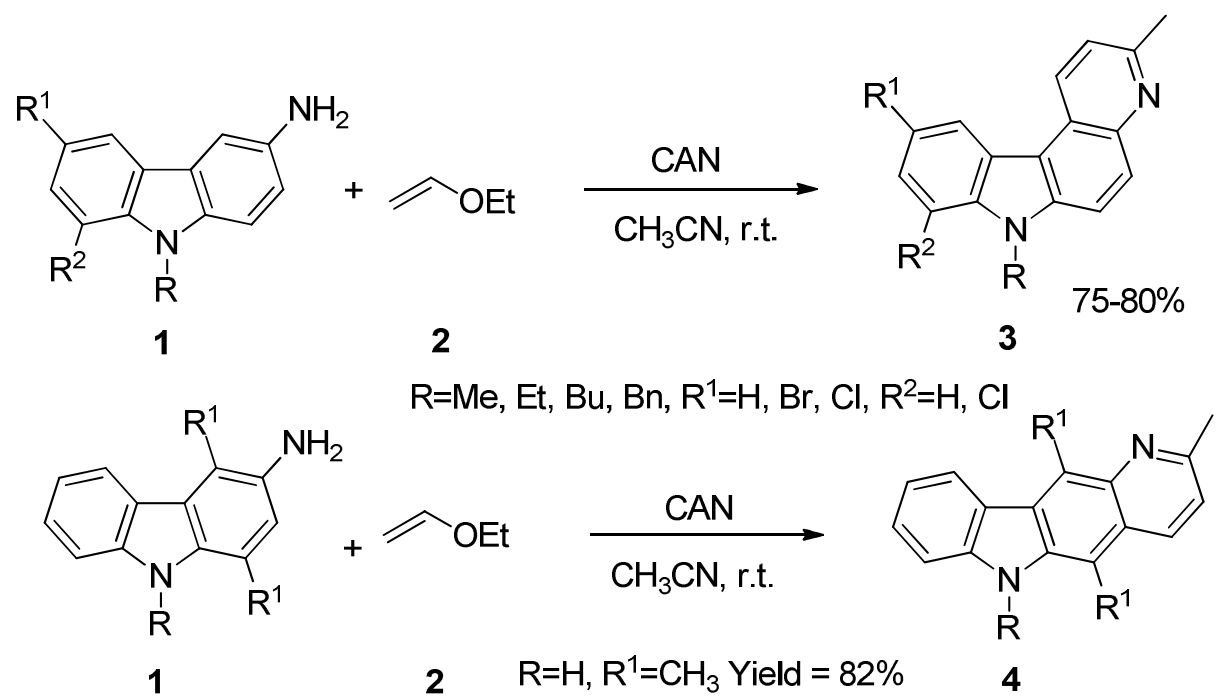

$\mathrm{R}=\mathrm{Et}, \mathrm{R}^{1}=\mathrm{CH}_{3}$ Yield $=80 \%$

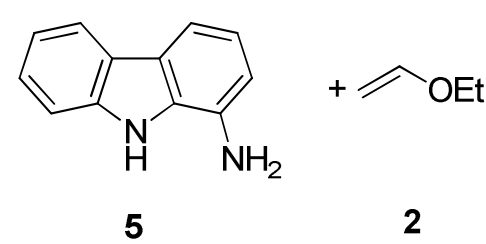

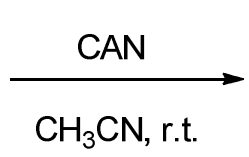

$\mathrm{CH}_{3} \mathrm{CN}$, r.t.

2

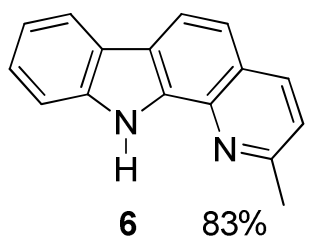

\section{Scheme 1}

\subsection{Pyrido[2,3-c]carbazol-1-ones}

The reaction of 9-alkyl-3-aminocarbazoles 1 with ethyl-3-oxobutanoate in benzene in the presence of a catalytic amount of hydrochloric acid yielded mixture of two products the amide $\mathbf{8}$ and the condensation product ethyl 3-[(9-ethylcarbazol-3-yl)amino]-2-butenoate 7 in a 1:4 ratio. The condensation products 7 were cyclized to the corresponding 4,7-dihydropyrido[2,3-c]carbazol-1-ones 9 upon heating in mineral oil at 240-250 ${ }^{\circ} \mathrm{C}$ (Scheme 2). ${ }^{77}$ The synthesized compounds were studied by NMR spectra. Molecular modeling data supported the findings deduced from the ${ }^{13} \mathrm{C}-\mathrm{NMR}$ and ${ }^{1} \mathrm{H}-\mathrm{NMR}$ spectra. 


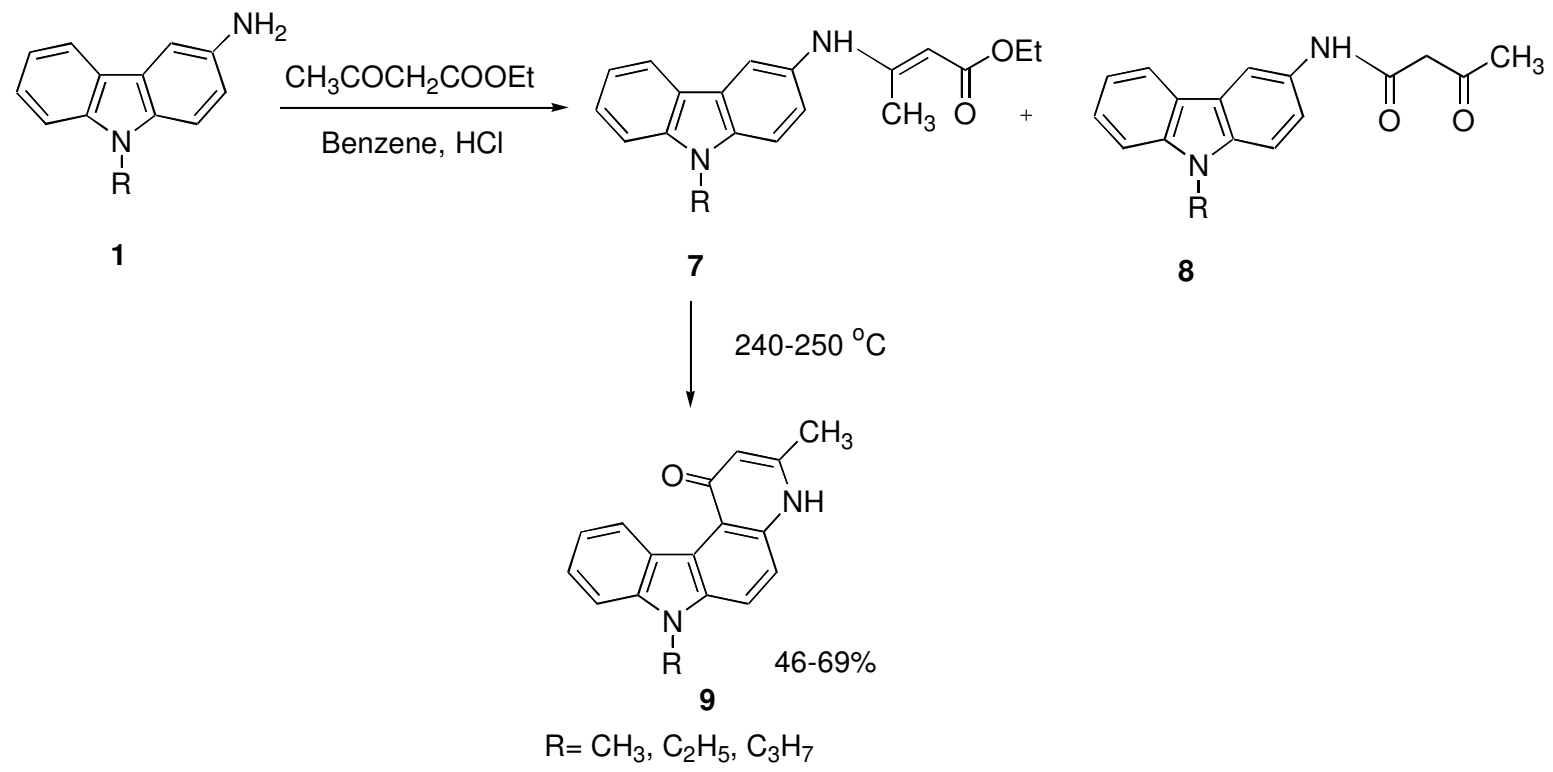

\section{Scheme 2}

\subsection{Hydroxypyridocarbazoles}

The reaction of 1-aminocarbazole $\mathbf{5}$ with ethoxymethylenemalonic ester $\mathbf{1 0}$ under mild heating conditions furnished $\alpha$-carbethoxy- $\beta$-(1-carbazolylamino)acrylate $\mathbf{1 1}$ which was cyclized by heating under reflux in diphenyl ether. The resulting ester was hydrolyzed with aqueous alkali and the acid decarboxylated to the corresponding hydroxypyridocarbazole 12 (Scheme 3 ). ${ }^{78}$<smiles>Nc1cccc2c1[nH]c1ccccc12</smiles>

5

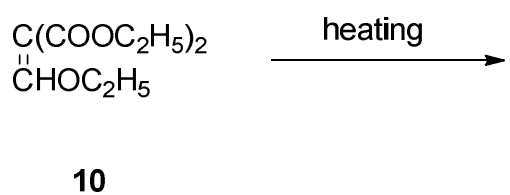

10

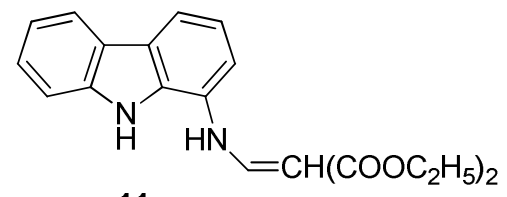

11

$82 \%$

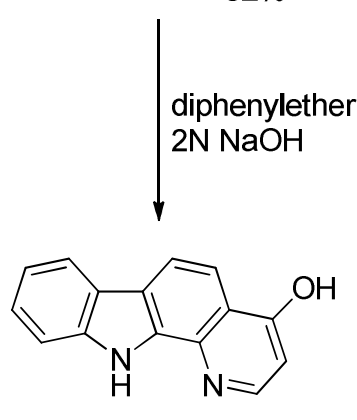

12

\section{Scheme 3}




\subsection{Dihydropyridocarbazoles}

Recently, various iodo-substituted dihydropyridocarbazole derivatives were synthesized via $\mathrm{N}$ propargylated 3-aminocarbazoles (Scheme 4). ${ }^{79}$

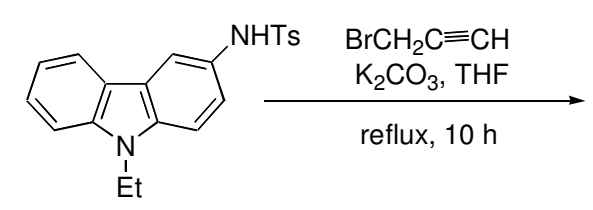

13

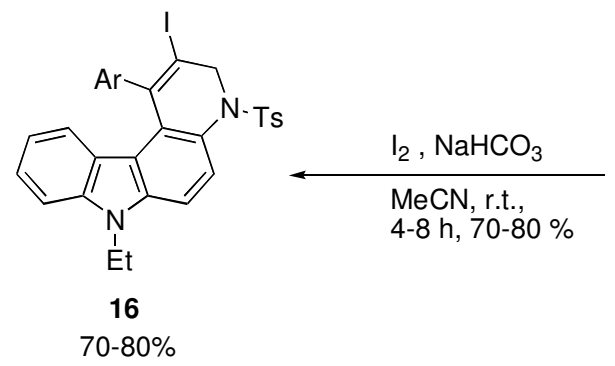

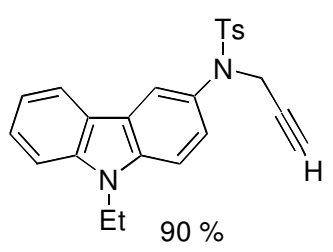

14
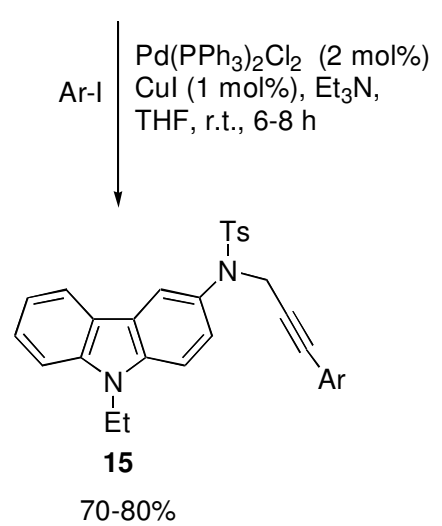

\section{Scheme 4}

Propargylation of $\mathrm{N}$-tosylated aminocarbazole 13 with propargyl bromide in the presence of $\mathrm{K}_{2} \mathrm{CO}_{3}$ in THF offered propargylated aminocarbazole 14 with good yield. The obtained product 14 was subjected to Sonogashira coupling with various aryl iodides in the presence of $\mathrm{Pd}\left(\mathrm{PPh}_{3}\right)_{2} \mathrm{Cl}_{2}$ and $\mathrm{CuI}$ in THF yielded disubstituted alkynes 15. Then iodocyclization reaction with iodine and $\mathrm{NaHCO}_{3}$ in acetonitrile produced the corresponding iodo-substituted dihydropyridocarbazole derivatives $\mathbf{1 6}$ in good yields (Scheme 4).

\section{Synthesis of Isomeric Ellipticine Derivatives}

Ellipticine, an alkaloid and several of its derivatives exhibit promising results in the treatment of osteolytic breast cancer metastases, brain tumors, kidney sarcoma, and myeloblastic leukemia. ${ }^{80}$ More recent studies have also indicated activity against HIV. ${ }^{81}$ The main reason for the interest in ellipticine and its derivatives for clinical purposes is their high efficiency against several types of cancer, limited toxic side effects, and a complete lack of hematological toxicity. ${ }^{82}$

An efficient, three component, one-pot synthesis of new isomeric ellipticine derivatives 19, 20 were prepared through an intermolecular imino Diels-Alder reaction of 3-aminocarbazoles 1 and benzaldehyde 17 with electron-rich alkenes 18 such as 3,4-dihydro- $H$-pyran, 2,3- 
dihydrofuran and ethyl vinyl ether catalyzed by $\mathrm{InCl}_{3}(10 \mathrm{~mol} \%)$ in ionic liquid (Scheme 5$) .{ }^{83}$ In the case of substituted benzaldehydes, reductive amination was observed.

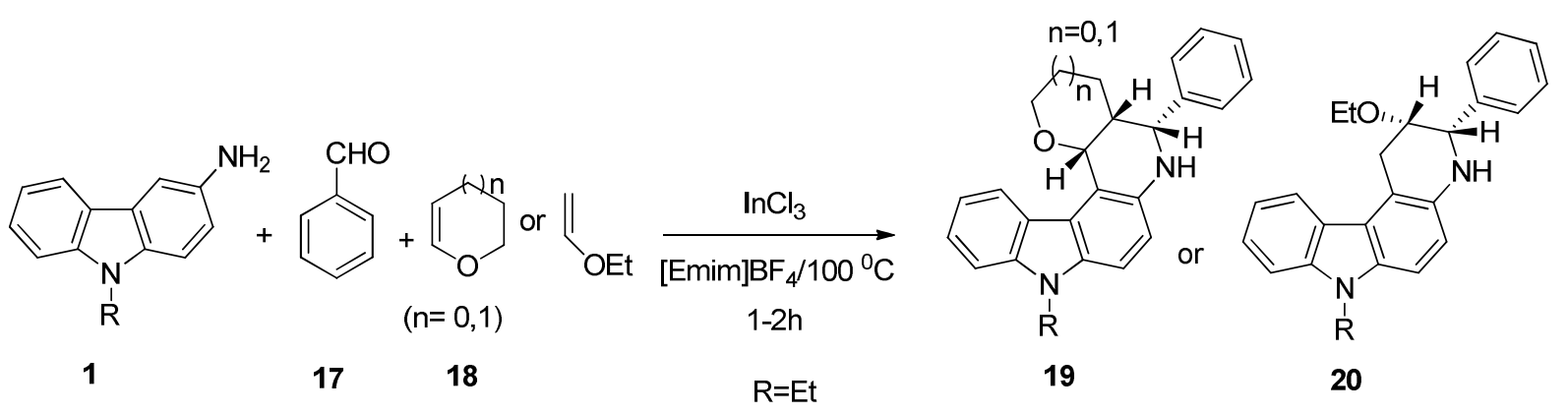

\section{Scheme 5}

Similarly, a mild, efficient and highly selective approach to the synthesis of cryptolcarbazole derivatives $\mathbf{2 2}$ via three-component reactions of 3-amino-9-ethylcarbazole $\mathbf{1}$ and aromatic aldehydes 21 with electron-rich alkenes $\mathbf{1 8}$ was reported (Scheme 6). ${ }^{84}$ It was found that the tetrahydropyran ring and six-membered piperidine rings were cis fused and trans to Ar substituent. Products were obtained in good to high yields, with high selectivity being confirmed by X-ray diffraction analysis.

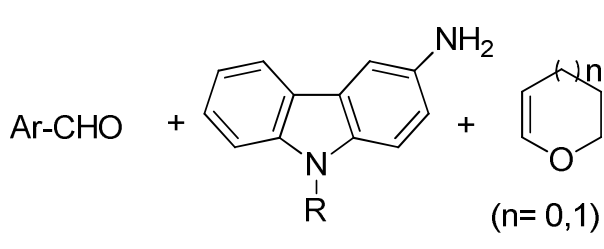

21

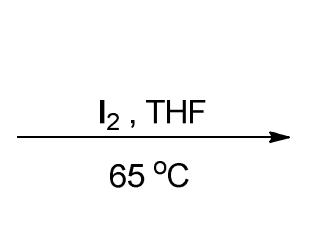

$\mathrm{R}=\mathrm{Et}$

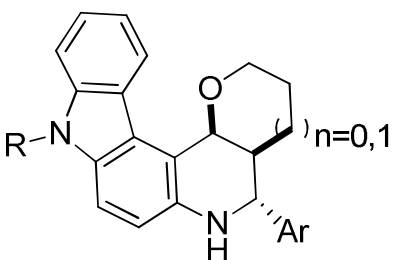

22

$70-88 \%$

\section{Scheme 6}

Various isomeric ellipticine derivatives were synthesized from aminocarbazoles utilizing a novel [4+2] cycloaddition reaction (Scheme 7). ${ }^{85}$ The imino Diels-Alder reaction of $N$ prenylated-2-formyl-3-chloroindole $\mathbf{2 3}$ with various substituted aminocarbazoles $\mathbf{1}$ in the presence of $\mathrm{La}(\mathrm{OTf})_{3}(10 \mathrm{~mol} \%)$ under the optimized conditions yielded the corresponding imino Diels-Alder products 24 in excellent yields. Cycloaddition of $\mathbf{1}$ with 25 at $100{ }^{\circ} \mathrm{C}$ proceeded efficiently in 1,4-dioxane to afford $\mathbf{2 6}$ in excellent yield with higher diastereoselectivity ratio; the cis isomer is the major product. Similarly, the reaction of aminocarbazoles $\mathbf{1}$ with aliphatic aldehyde $\mathbf{2 7}$ as a dienophile proceeded smoothly to afford $\mathbf{2 8}$ with good yield. Interestingly, in this case the trans isomer was the major product. 


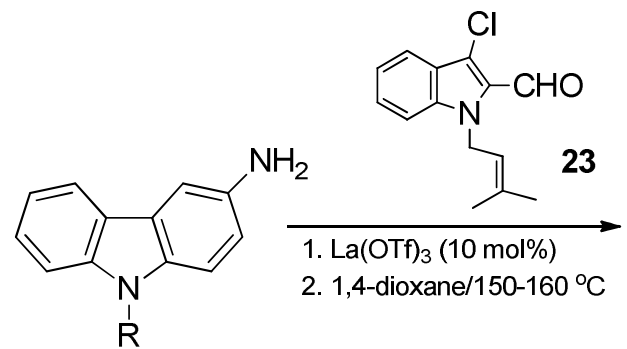

1

$\mathrm{R}=\mathrm{H}, \mathrm{Me}, \mathrm{Et}$,

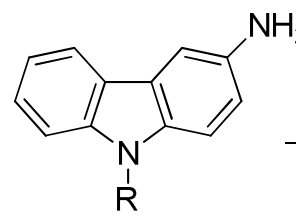

1

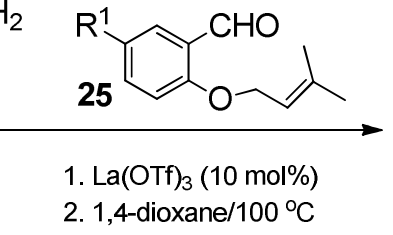

$\mathrm{R}=\mathrm{Et}, \mathrm{R}^{1}=\mathrm{H}, \mathrm{Br}, \mathrm{Cl}, \mathrm{Me}, \mathrm{OMe}$

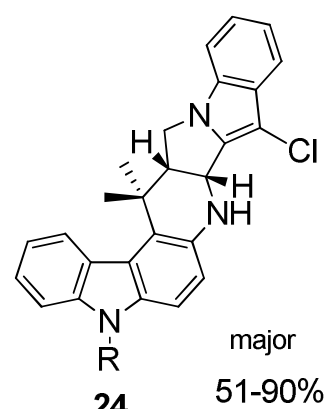

24

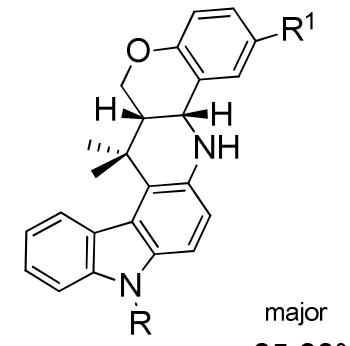

26

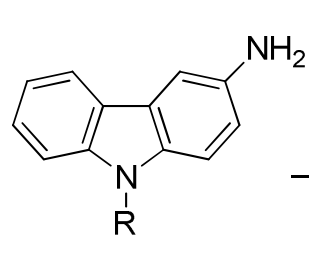

1

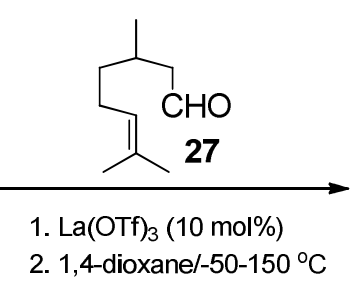

$\mathrm{R}=\mathrm{Et}$

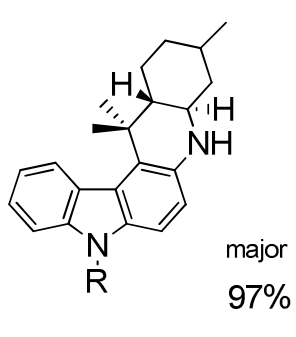

28

\section{Scheme 7}

In another work, a one-pot synthesis of isomeric ellipticine derivatives through $\mathrm{CuI} / \mathrm{La}(\mathrm{OTf})_{3}$ catalyzed sequential inter/intramolecular cyclization of substituted alkynes with imines followed by aromatization was reported (Scheme 8$).{ }^{86}$ The reaction of imine derived from aminocarbazole 1 and aldehyde 29 with phenylacetylene 30 in the presence of $\mathrm{CuI} / \mathrm{La}(\mathrm{OTf})_{3}$ in $[\mathrm{Bmim}] \mathrm{BF}_{4}$ afforded 31 along with the side product. One equivalent of imine underwent the cyclization with phenylacetylene to dihydropyridocarbazole, which further aromatized to the product 31. CuI was found to be efficient and necessary catalyst to activate the triple bond. It was observed that substituents having an electron poor or electron rich or heteroaromatic group gave the desired products in good to excellent yields. 


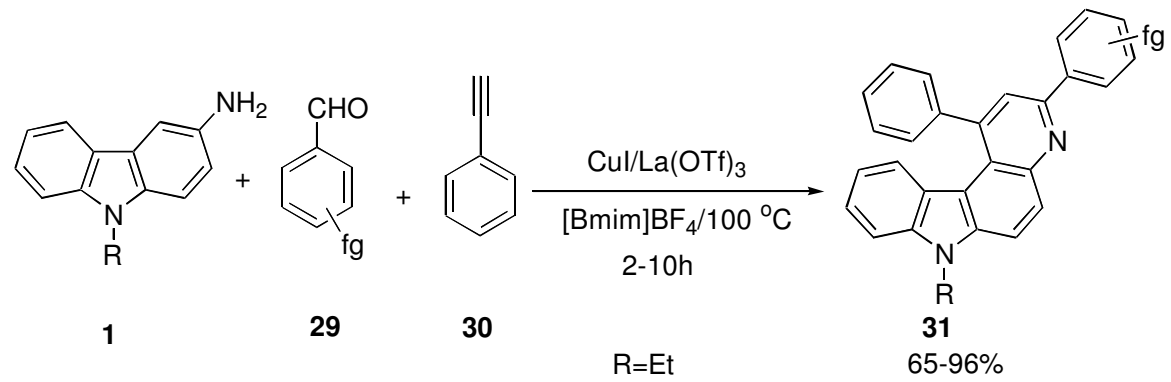

\section{Scheme 8}

The reaction of $O$-propargylated salicylaldehydes 32 with 3 -aminocarbazole $\mathbf{1}$ in the presence of $\mathrm{CuI} / \mathrm{La}(\mathrm{OTf})_{3}$ in ionic liquid yielded the corresponding intramolecular cyclization products $\mathbf{3 3}$ in excellent yields and the cyclization occurs through the fourth position of the carbazole ring (Scheme 9).

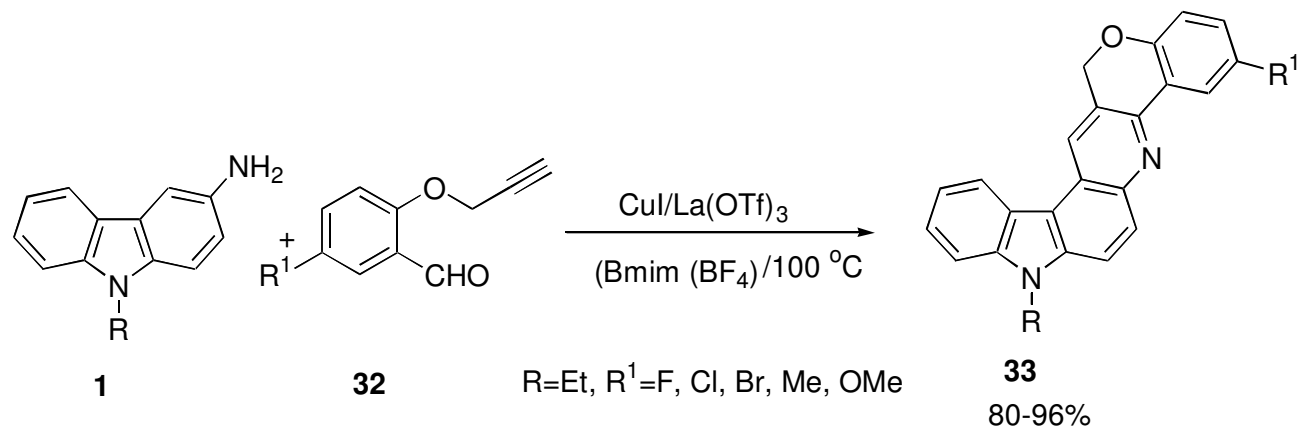

\section{Scheme 9}

Similarly, the intermolecular reaction of diaminocarbazole $\mathbf{1}$ with benzaldehyde $\mathbf{1 7}$, phenylacetylene $\mathbf{3 0}$ under the same reaction conditions proceeded well and furnished the corresponding product 34 in $62 \%$ yield (Scheme 10). The structure of the product 34 was confirmed by single crystal analysis. Also, the intramolecular pathway of diaminocarbazole 1 with $O$-propargylated salicylaldehyde 32 gave the product $\mathbf{3 5}$ in $76 \%$ and there was no monocyclized product observed.

A one-pot synthesis of quinolines via molecular iodine-catalyzed and air-mediated tandem condensation/imino-Diels-Alder/isomerization/oxidation of simple readily available amines, aldehydes, and alkynes was reported. ${ }^{87}$ This methodology was extended to the polycyclic aromatic 9-ethylcarbazol-3-amine. The reaction of 9-ethylcarbazol-3-amine 1, benzaldehyde 17 and phenylacetylene $\mathbf{3 0}$ in nitromethane in the presence of molecular iodine and air produced the ellipticine isomer 36 in $68 \%$ yield (Scheme 11). This has been done by assembling the quinoline core via a one-pot three component reaction from $[3+2+1]$ atom fragments by formation of three new bonds. 


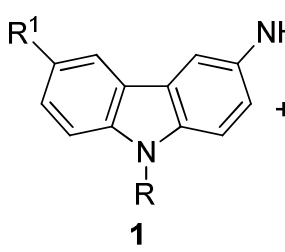

$\mathrm{R}=\mathrm{H}, \mathrm{R}^{1}=\mathrm{NH}_{2}$<smiles>O=Cc1ccccc1</smiles>

17

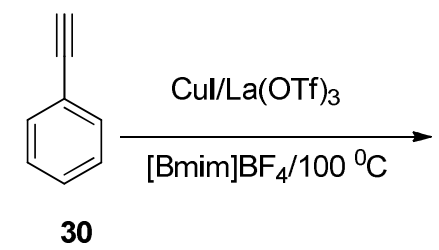

30

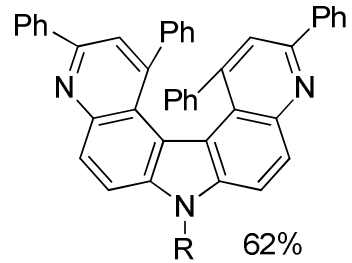

34

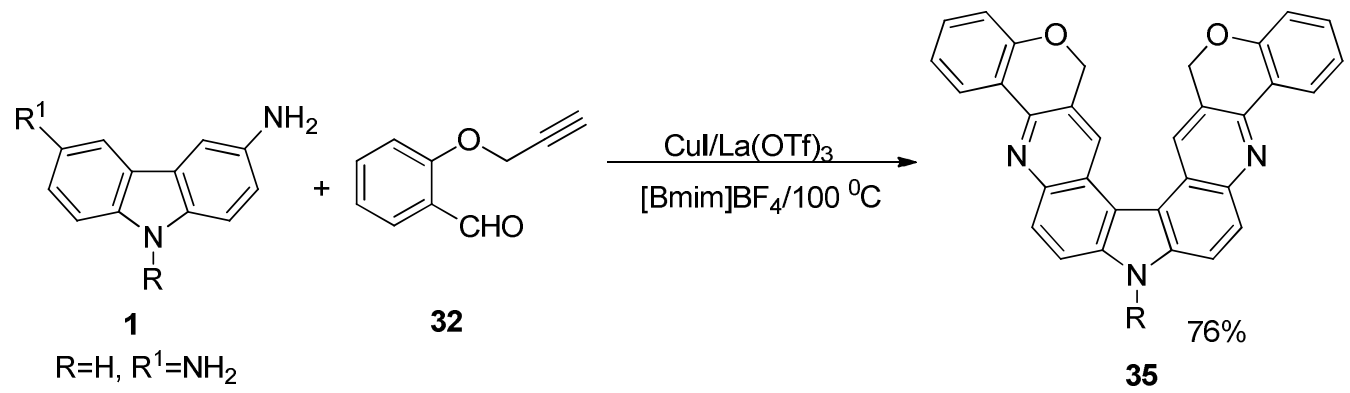

\section{Scheme 10}<smiles>[R]n1c2ccccc2c2cc(N)ccc21</smiles>

1<smiles>O=CC1=C[C+]=CC=C1</smiles>

17

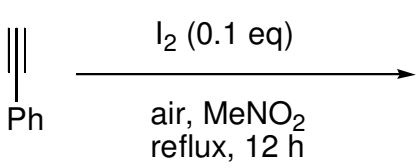

$\mathrm{R}=\mathrm{Et}$<smiles>[R]n1c2ccccc2c2c3c(-c4ccccc4)cc(-c4ccccc4)nc3ccc21</smiles>

36

Scheme 11

\section{Synthesis of Thiazolocarbazoles}

\subsection{Thiazolocarbazolecarbonitriles}

2-Cyanobenzothiazole is an important pharmacophore with proven and potential bioactivities. ${ }^{88}$ Reaction of aminocarbazole 1 with 4,5-dichloro-1,2,3-dithiazolium chloride 37 was carried out in dichloromethane at room temperature, followed by addition of pyridine, to give the desired (1,2,3-dithiazol-5-ylideneamino)carbazole $\mathbf{3 8}$ in $73 \%$ yield. Compound $\mathbf{3 8}$ was heated at $200{ }^{\circ} \mathrm{C}$ in the presence of diphenyl ether for 30 minutes to afford the thiazolocarbazolecarbonitrile 39 (Scheme 12). ${ }^{89}$ 


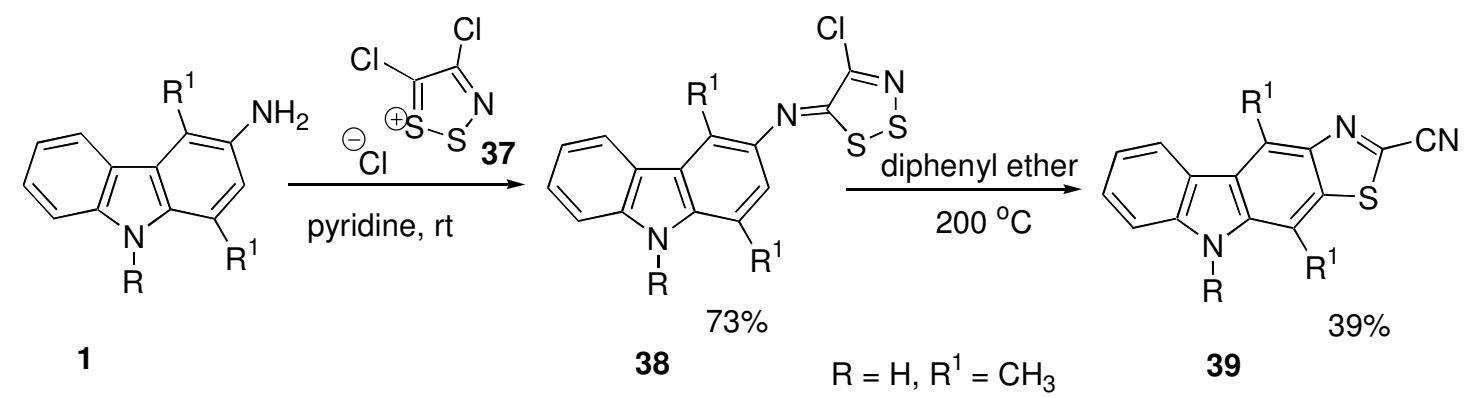

\section{Scheme 12}

Following a similar strategy, demethylated analogues of ellipticine were prepared from various 3-aminocarbazoles $\mathbf{1}$ via the corresponding imino-1,2,3-dithiazoles $\mathbf{4 0}$. Whatever thermolysis conditions were used, the wanted linear thiazolocarbazolecarbonitriles $\mathbf{4 2}$ were the minor products, whilst their angular counterparts $\mathbf{4 1}$ were the major ones (Scheme 13).

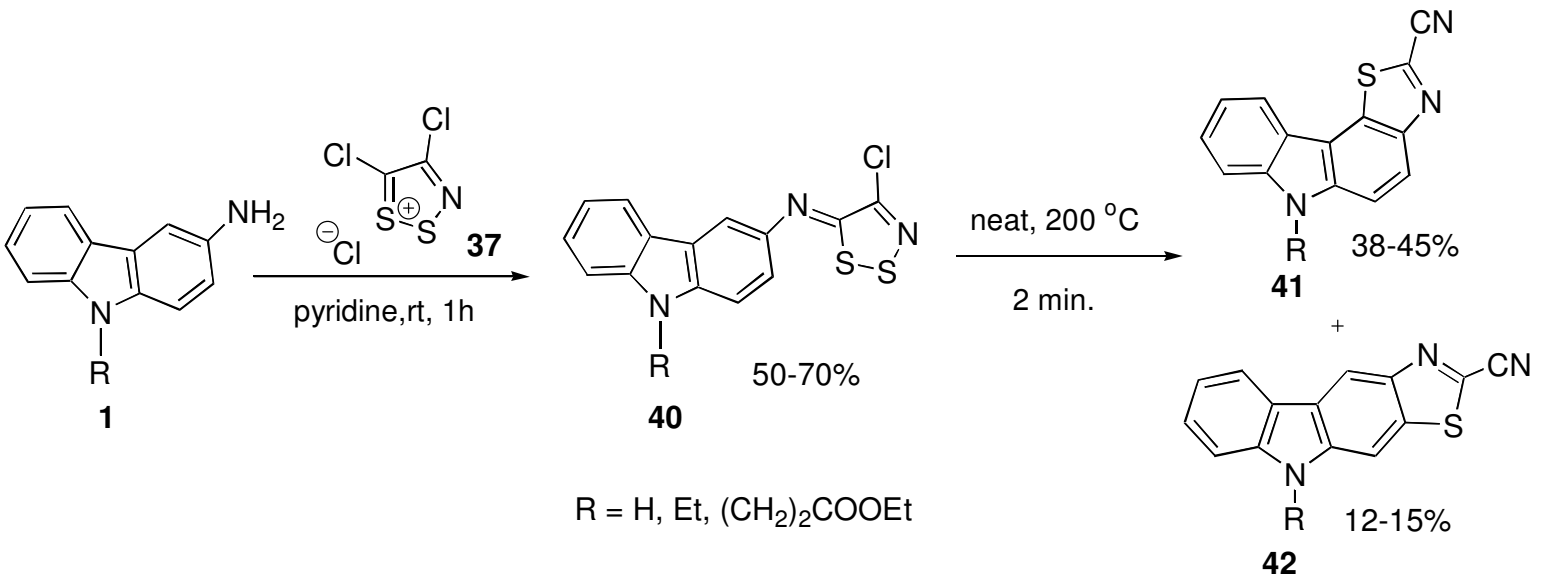

\section{Scheme 13}

\subsection{2-Aminothiazolocarbazoles}

The 3-aminocarbazoles $\mathbf{1}$ were condensed with phenyl and benzyl isothiocyanates on montmorillonite K10 clay or TLC-grade silica gel at room temperature to furnish the $N$-phenyl and $N$-benzylthioureidocarbazoles 43. The later compounds 43 were adsorbed on montmorillonite K10 clay impregnated with $p$-toluenesulfonic acid $(1: 1, \mathrm{w} / \mathrm{w})$ and heated at 60 $70{ }^{\circ} \mathrm{C}$ to afford the 2-anilino and 2-benzylaminothiazolo[4,5-c]carbazoles 44 regioselectively in high yields. The cyclisation was also effective for the $N$-methylthioureidocarbazoles $\mathbf{4 5}$ (Scheme 14). ${ }^{90}$ 


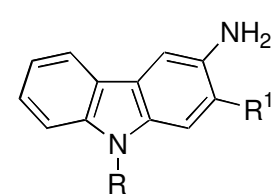

1

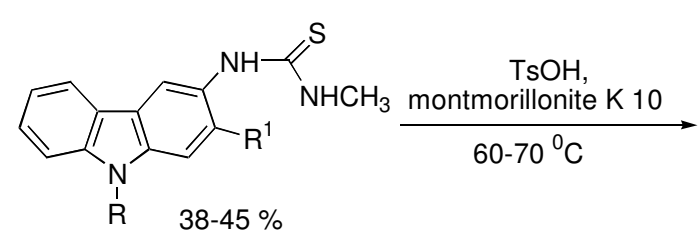

45

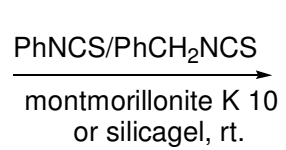

or silicagel, rt.
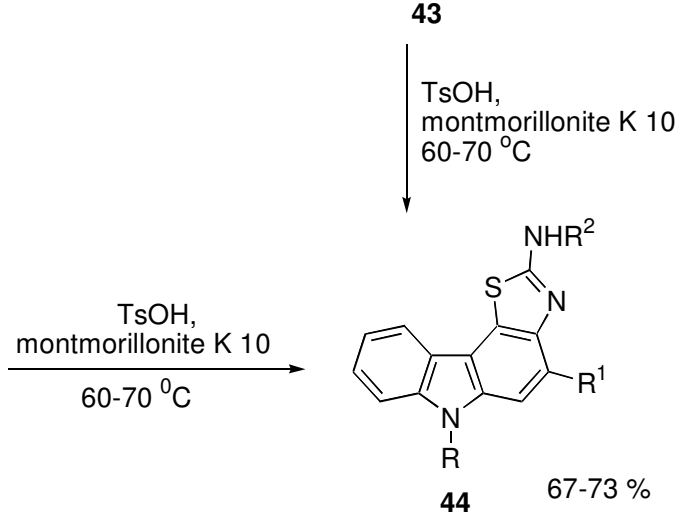

$\mathrm{R}=\mathrm{H}, \mathrm{Me}, \mathrm{Et}, \mathrm{n}-\mathrm{Pr}, \mathrm{R}^{1}=\mathrm{H}, \mathrm{Me}, \mathrm{R}^{2}=\mathrm{Ph}, \mathrm{PhCH}_{2}, \mathrm{Me}$

\section{Scheme 14}

\section{Synthesis of Pyrimidocarbazoles}

The ethoxycarbonyl protected guanidine intermediate 46 was prepared in two steps realized in one-pot and in nearly quantitative yield from 3-aminocarbazole 1. The intermediate 46 was subjected to Friedel-Crafts intramolecular cyclization under microwave irradiation using montmorillonite K-10 clay as a catalyst to gave tetracyclic pyrimido[4,5-c]carbazole $\mathbf{4 7}$ in $77 \%$ yield (Scheme 15). ${ }^{91}$ The pyrimido[4,5-c]carbazole derivative showed significant micromolar $\mathrm{IC}_{50}$ against cancer cell lines.

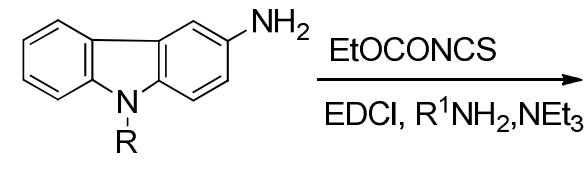

1

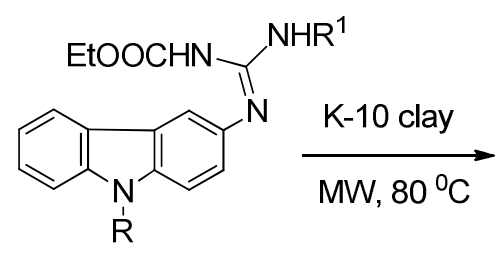

46<smiles>[R]Nc1nc2ccc3c(c4ccccc4n3[R])c2c(=O)[nH]1</smiles>

47

$\mathrm{R}=\mathrm{Et},-\left(\mathrm{CH}_{2}\right)_{2}-\mathrm{NMe}_{2}$

\section{Scheme 15}

Several 2-dialkylamino-5,11-dimethyl-6H-pyrimido[5,4- $b]$ carbazol-4(3H)-ones $\mathbf{5 0}$ were prepared in a simple one-pot reaction starting from 3 -aminocarbazoles. ${ }^{92}$ The aminocarbazoles $\mathbf{1}$ were treated with ethoxycarbonylisothiocyanate to give thiourea intermediates $\mathbf{4 8}$, followed by 
the addition of an alkylamine and $\mathrm{HgCl}_{2}$ to give ethoxycarbonylguanidine intermediates 49 . The reaction mixture was then heated at $160{ }^{\circ} \mathrm{C}$ to give the 2-dialkylamino-5,11-dimethyl-6Hpyrimido[5,4- $b$ ]carbazol-4(3H)-ones $\mathbf{5 0}$ (Scheme 16).

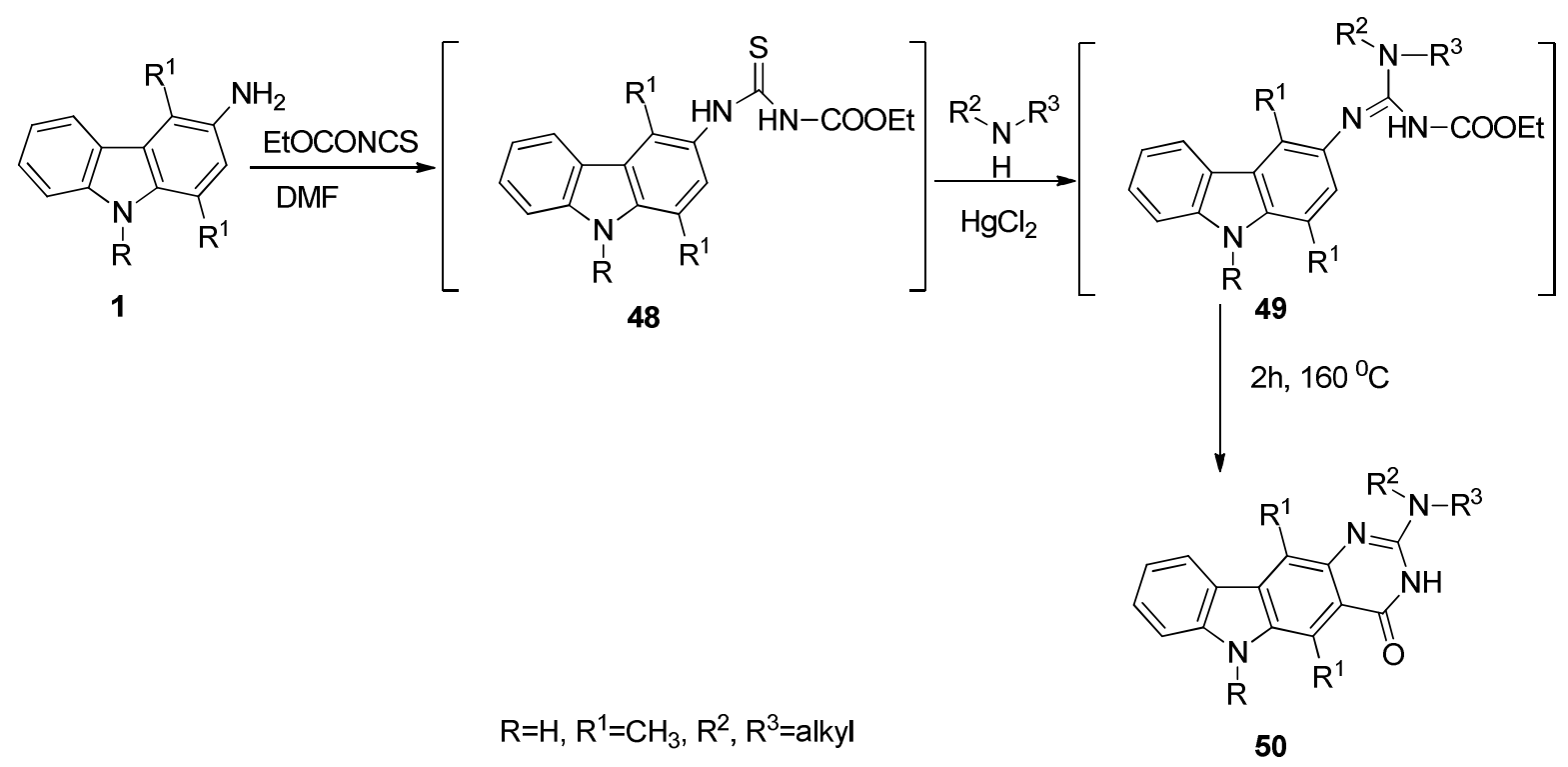

\section{Scheme 16}

\section{Synthesis of Pyrrolo- and Indolo-carbazoles}

Pyrrolo[2,3-a] and [3,4-c]carbazoles have great importance due to their inhibiting properties toward pim kinase inhibitors ${ }^{93}$ and Chk1 inhibitors, ${ }^{94}$ respectively. Indolocarbazole, the benzene analog of pyrrolocarbazole have received great attention because of their existence in many natural products with potent biological activities. ${ }^{95}$

Pyrrolo[2,3-c]carbazoles $\mathbf{5 2}$ were synthesized from $N$-alkylated-3-aminocarbazoles $\mathbf{1}$ and ethylene glycol 51 via heteroannulation reaction using $\mathrm{RuCl}_{3} / \mathrm{SnCl}_{2}$ (Scheme 17). ${ }^{96}$ The best yields were obtained when the reactions were carried out in toluene. It was observed that without the addition of $\mathrm{SnCl}_{2}$ heteroannulation reaction did not proceed. $\mathrm{RuCl}_{3}$ was found to be an efficient catalyst in this reaction compared with other catalysts. The authors found that dppe was the most effective ligand for this reaction. The desired indolo[2,3-c]carbazoles $\mathbf{5 4}$ were successfully synthesized in good yields by reacting acetonylacetone $\mathbf{5 3}$ with various pyrrolo[2,3-c]carbazoles $\mathbf{5 2}$ using $p$-toluenesulfonic acid as a catalyst. 


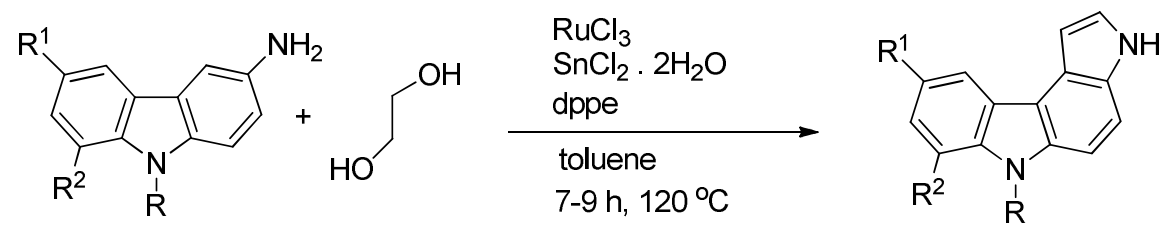

1

51

52

$\mathrm{R}=\mathrm{Et}, \mathrm{Me}, \mathrm{n}-\mathrm{Bu}, \mathrm{Bn}, \mathrm{R}^{1}=\mathrm{H}, \mathrm{Cl}, \mathrm{Br}, \mathrm{Me}, \mathrm{R}^{2}=\mathrm{H}, \mathrm{Cl} \quad 71-75 \%$<smiles>[R]c1cc([R])c2c(c1)c1c3cc[nH]c3ccc1n2[R]</smiles>

52<smiles>CC(=O)CCC(C)=O</smiles>

53

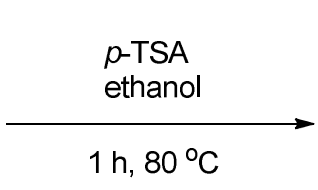

$1 \mathrm{~h}, 80^{\circ} \mathrm{C}$<smiles>[R]c1cc([R])c2c(c1)c1c3c(ccc1n2[R])[nH]c1c(C)ccc(C)c13</smiles>

54

$74-80 \%$

$\mathrm{R}=\mathrm{Et}, \mathrm{Me}, \mathrm{R}^{1}=\mathrm{H}, \mathrm{Cl}, \mathrm{R}^{2}=\mathrm{H}, \mathrm{Cl}$

\section{Scheme 17}

Pyrrolo[2,3-c]carbazoles 56 were also synthesized by zinc triflate catalyzed heteroannulation reaction of 3-aminocarbazoles with substituted propargyl alcohols $\mathbf{5 5}$ moderate to good yields (Scheme 18). ${ }^{97}$ This transformation proceeded with good regioselectivity and without the addition of additives or ligands.

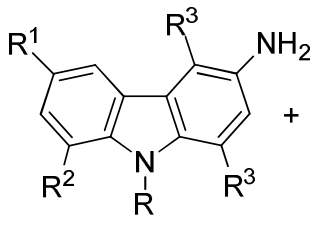

1

$\mathrm{R}^{1}=\mathrm{Ht}, \mathrm{Cl}, \mathrm{Br}$

$\mathrm{R}^{2}=\mathrm{H}, \mathrm{Cl}$

$\mathrm{R}=\mathrm{Me}, \mathrm{Et}, \mathrm{n}-\mathrm{Bu}, \mathrm{Bn}$

$\mathrm{R}^{3}=\mathrm{H}$, Mel

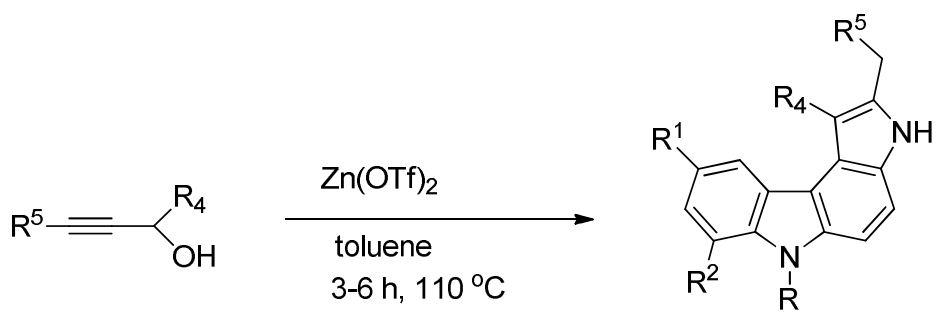

55

$\mathrm{R}^{4}=\mathrm{H}, \mathrm{Me}, \mathrm{Ph}$

$\mathrm{R}^{5}=\mathrm{H}, \mathrm{Ph}, \mathrm{PhMe}$
56

$65-82 \%$

\section{Scheme 18}




\section{Synthesis of Quino- and Chromeno-carbazoles}

Quino and chromenocarbazoles were synthesized from aminocarbazoles in two steps based on $\mathrm{C}-\mathrm{N}$ and $\mathrm{C}-\mathrm{O}$ bond formation through Ullmann-Goldberg condensation followed by intramolecular Friedel-Crafts cyclization. ${ }^{98}$ As shown in Scheme 19, the condensation of 3amino-9-ethylcarbazole 1 with various $o$-iodobenzoic acids $\mathbf{5 7}$ in presence of $\mathrm{CuI}$ and $\mathrm{K}_{2} \mathrm{CO}_{3}$ without any ligand in DMSO at $80{ }^{\circ} \mathrm{C}$ to give products $\mathbf{5 8}$. The later compounds $\mathbf{5 8}$ were subjected to cyclization with $\mathrm{POCl}_{3}$ at $60{ }^{\circ} \mathrm{C}$ to afford the corresponding products $\mathbf{5 9}$ in good yields. The reaction works well for other substituted $o$-halobenzoic acids. When the reaction was performed at $120{ }^{\circ} \mathrm{C}$, two regioisomeric quinocarbazoles were formed. Compounds $\mathbf{6 0}$ were formed as a major products along with minor products 61 (Scheme 19).

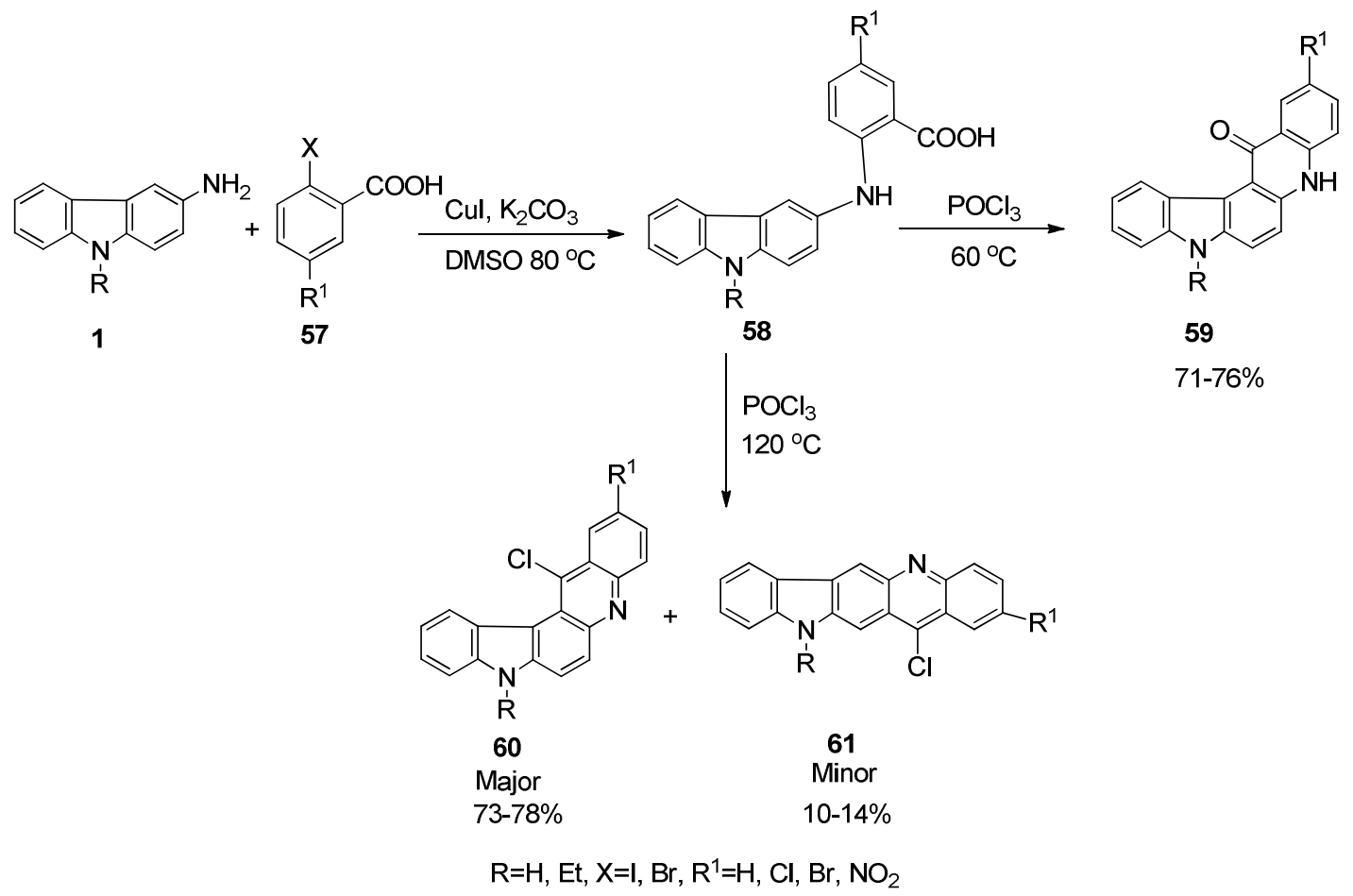

\section{Scheme 19}

\section{Synthesis of Fused Naphthyridines}

Benzonaphthyridines have recently been patented as new generation growth regulators, fungicides, bactericides, herbicides, and insecticides. Moreover, some benzo[ $h]$ naphthyridines exhibit remarkable biological and pharmacological activities such as antimalarial and as antagonists of the 5-HT4 receptor. ${ }^{99}$ 
Microwave assisted $p$-TsOH-catalyzed synthesis of benzo[6,7][1,8]naphthyridino[3,2- $b]$ carbazoles 63 via a one pot reaction of 3-amino-9-ethylcarbazole 1 and 2-chloro-3formylquinolines 62 was reported (Scheme 20). ${ }^{100}$ The remarkable catalytic activity of $p$-TsOH was superior to other reported catalysts with respect to yields and reduced reaction times.

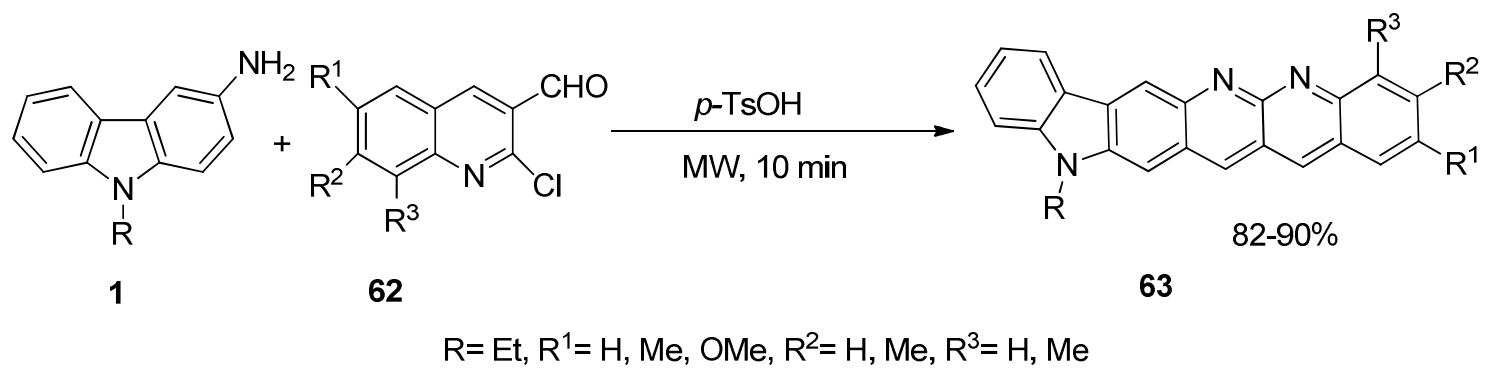

Scheme 20

\section{Synthesis of other Heterocycles}

A three-component synthesis of exo-tetrahydroindolo[3,2-c]quinoline derivatives $\mathbf{6 5}$ from the reaction of an aromatic aldehydes 21, 9-ethyl-9H-carbazol-3-amine $\mathbf{1}$ and indoles $\mathbf{6 4}$ with iodine as catalyst in toluene was reported (Scheme 21). ${ }^{101}$ The advantages of this method include mild reaction conditions, moderate yields, high stereoselectivity, metal-free catalyst, and operational simplicity.

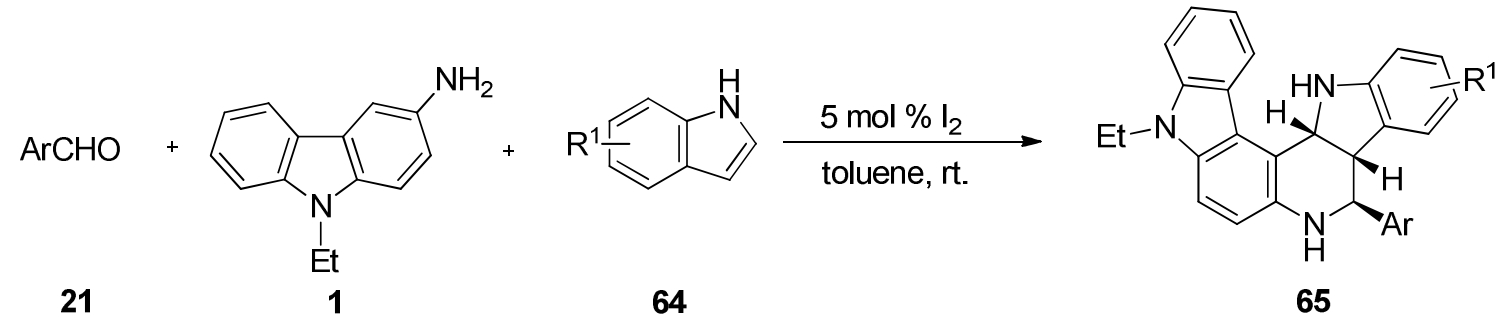

\section{Scheme 21}

Diindolophenazine derivatives 66 were synthesized by the aerobic oxidative coupling of 3aminocarbazoles 1 in the presence of catalytic $\mathrm{CuBr}$ in $\mathrm{DMSO}$ at $80{ }^{\circ} \mathrm{C}$ while open to air (Scheme 22). ${ }^{102}$ After screening a variety of solvents and catalysts, the best result was obtained in DMSO at $80^{\circ} \mathrm{C}$ for six hours using copper(I) bromide as the catalyst. DMSO may play the role of ligand by coordinating the copper salts. A variety of substituents such as $\mathrm{Me}, \mathrm{OMe}, \mathrm{Cl}, \mathrm{Br}$ are tolerated well on the aminocarbazole. 

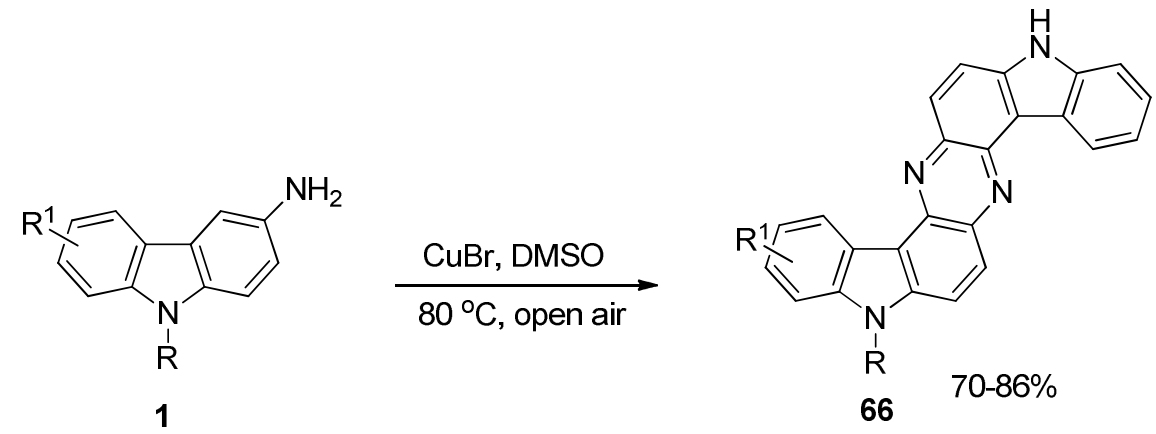

$\mathrm{R}=\mathrm{H}, \mathrm{Et}, \mathrm{Me}, \mathrm{R}^{1}=\mathrm{H}, \mathrm{Cl}, \mathrm{Br}, \mathrm{Me}, \mathrm{OMe}$

\section{Scheme 22}

A convenient one-pot three-component synthesis of 2-aryl-3-(9-alkylcarbazol-3-yl)thiazolidin-4-ones 68 from reaction of 3-amino-9-alkylcarbazoles 1, aromatic aldehydes 21 and 2mercaptoacetic acid 67 by using dicyclohexylcarbodimide as cyclizing agent in dry ether at room temperature was reported (Scheme 23). ${ }^{103}$ This protocol has advantages of mild condition, short reaction time, high yield and simple workup procedure.

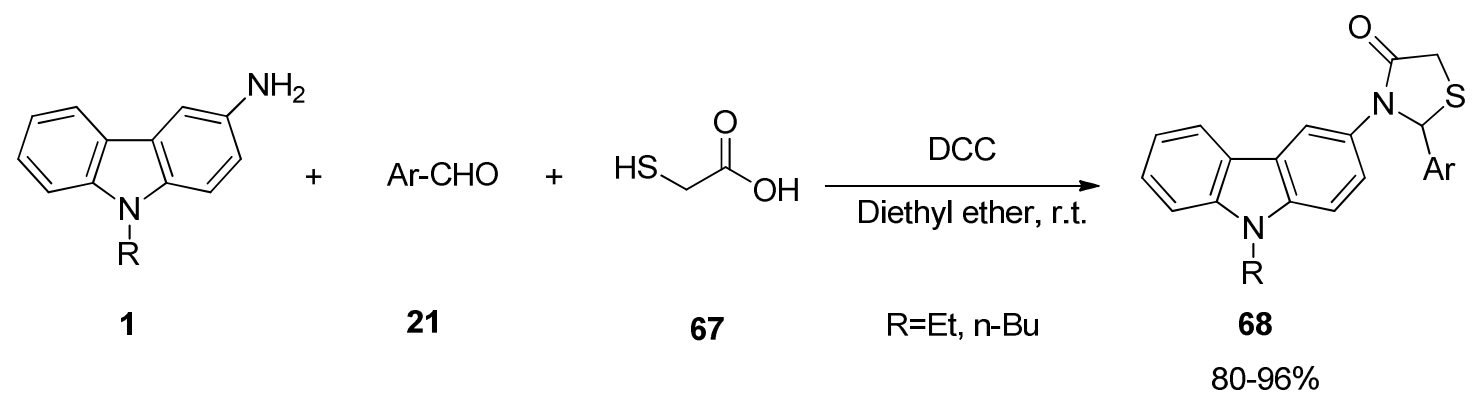

\section{Scheme 23}

The reaction of aromatic aldehydes 21, 3-amino-9-ethylcarbazole $\mathbf{1}$ and mercaptoacetic acid 67 under microwave irradiation (MW) under solvent free conditions offered the corresponding 1,4-thiazepine derivatives 69 (Scheme 24). ${ }^{104}$ The screen of solvent revealed that solvent-free condition was the best suitable condition for this reaction. These compounds have been subjected to testing for in vitro antioxidant and cytotoxic activities, resulting in the finding that these 1,4thiazepine derivatives not only have significant antioxidant activity, but also exhibit remarkably selective cytotoxicity to carcinoma cell line HCT 116.

Microwave-assisted eco-friendly four component reaction of 3-amino-9-ethylcarbazole 1, aromatic aldehydes 21, malononitrile $\mathbf{7 0}$ and acetylenic esters $\mathbf{7 1}$ using indium trichloride as catalyst offered $\mathrm{N}$-carbazolyldihydropyridines 72 in good yields (Scheme 25). ${ }^{105}$ The transformation was believed to proceed via Knoevenagel condensation, Michael addition, followed by tautomerization leading to the formation of products. The remarkable catalytic activity of $\mathrm{InCl}_{3}$ 
was superior to the other reported catalysts. Dimethyl acetylenedicarboxylate also showed very high reactivity. The use of microwave heating reduced reaction times and resulted in higher yields.

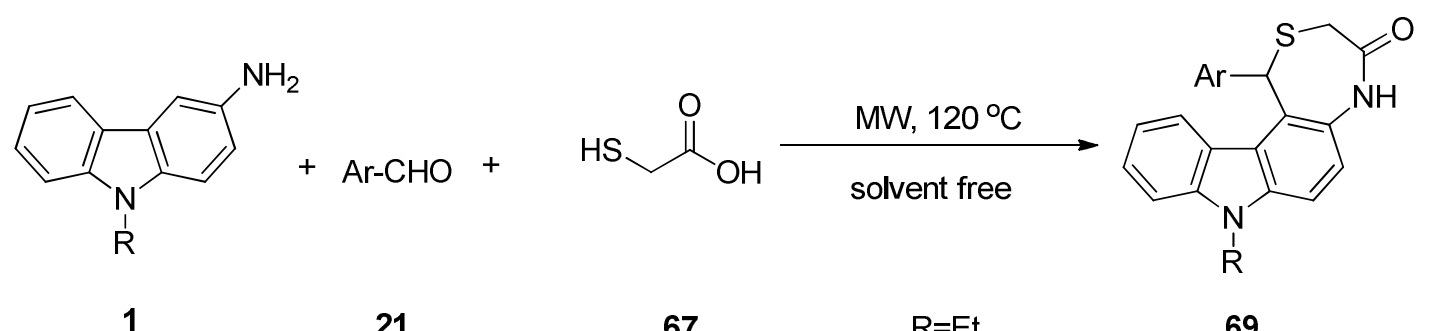

$76-93 \%$

\section{Scheme 24}

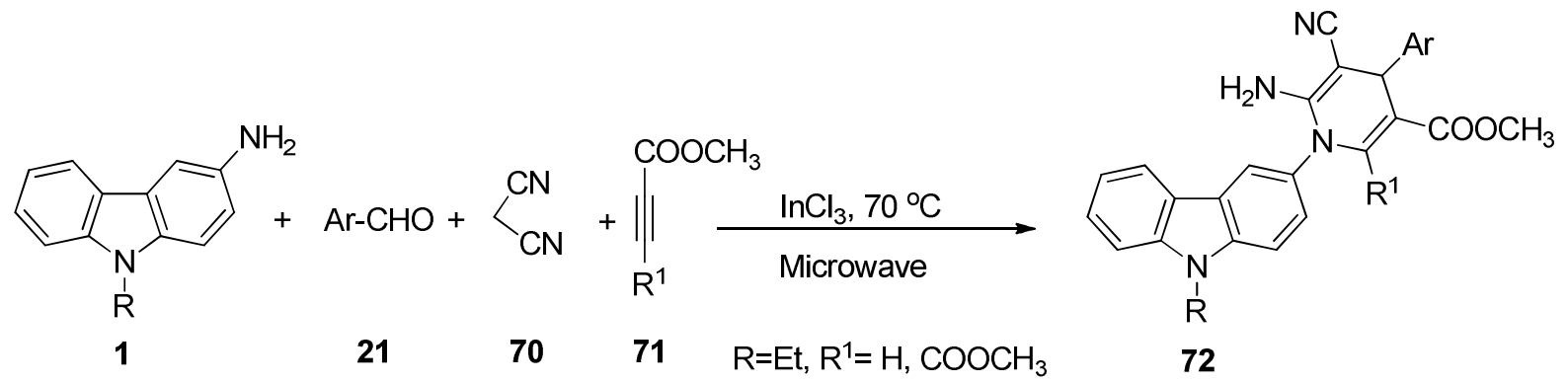

\section{Scheme 25}

An ionic liquid mediated, one-pot three-component strategy to synthesize carbazolyltetrahydropyrimidine derivatives $\mathbf{7 5}$ from 3-aminocarbazoles $\mathbf{1}$, formaldehyde $\mathbf{7 3}$ and dialkyl acetylenedicarboxylates 74 was reported (Scheme 26). ${ }^{106}$ It was observed that the maximum yield was obtained in the ionic liquid 1-butyl-3-methylimidazolium tetrafluoroborate $\left([\mathrm{Bmim}]\left[\mathrm{BF}_{4}\right]\right)$ without any catalyst.

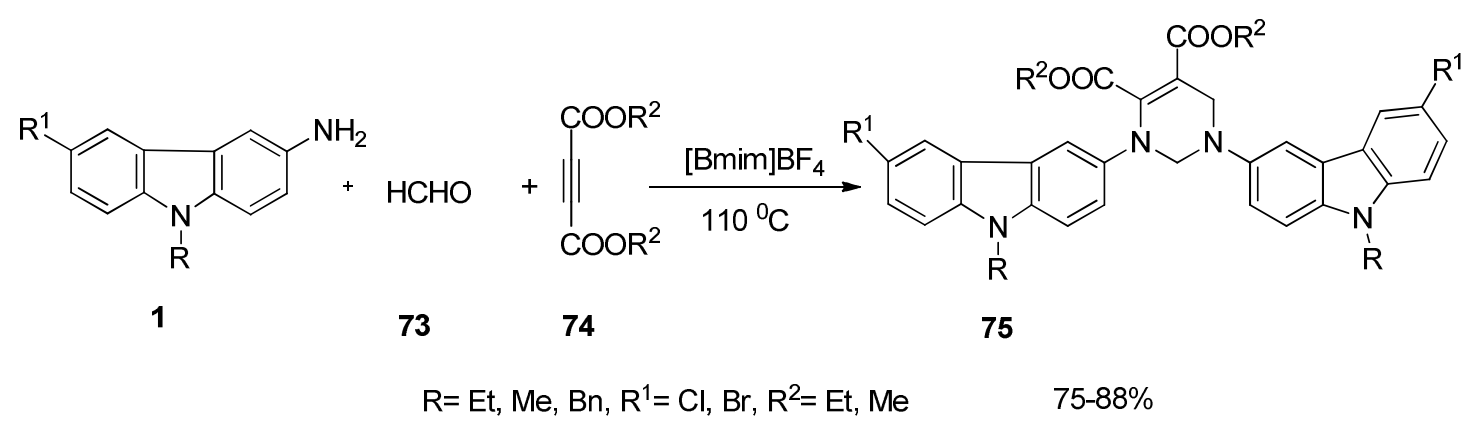

\section{Scheme 26}


Similarly, a three-component reaction of 3-aminocarbazoles $\mathbf{1}$, dialkyl acetylenedicarboxylates $\mathbf{7 4}$ and aromatic/heterocyclic aldehydes $\mathbf{2 1}$ for the synthesis of (carbazolylamino) furan-2(5H)-one derivatives 76 was reported (Scheme 27). ${ }^{106}$ It was found that potassium hydroxide was superior to the other bases.

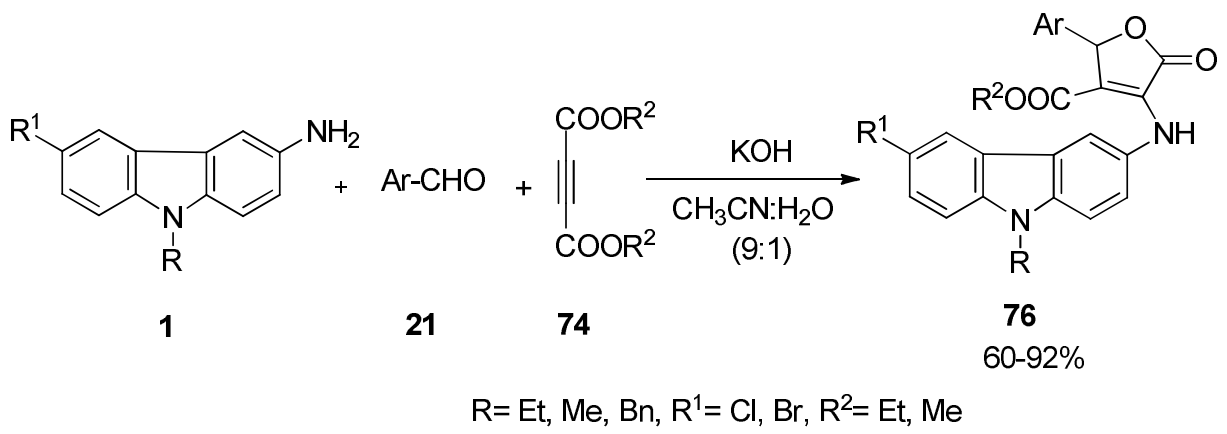

\section{Scheme 27}

Carbazole-based $\alpha$-aminophosphonates ${ }^{107}$ are known to possess considerable microbial and antioxidant behavior. The Kabachnik-Fields reaction of aminocarbazole $\mathbf{1}$ with aromatic aldehydes 21 and diphenyl/dialkyl phosphites 77 in the absent of catalyst under neat conditions at $25{ }^{\circ} \mathrm{C}$ gave the corresponding $\alpha$-aminophosphonates 78 (Scheme 28). ${ }^{108}$ This protocol has advantages of absence of catalyst under mild conditions and short period of times. The structure for one of these compounds has been confirmed by X-ray crystallography.

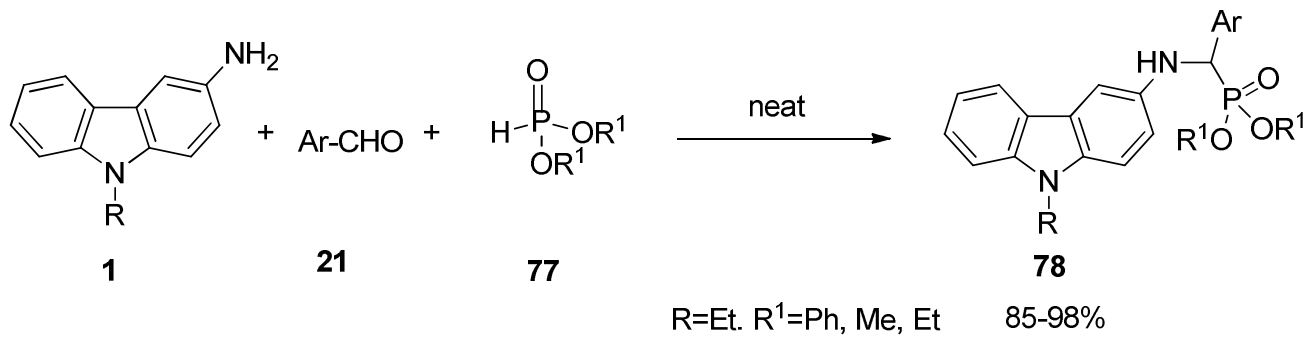

\section{Scheme 28}

\section{Conclusions}

This review highlights the advances in the use of aminocarbazoles as starting materials in the synthesis of wide variety of heterocycles of carbazole framework. Aminocarbazoles can become promising tools for diversity oriented synthesis. 


\section{Acknowledgements}

Padmaja thankful to DST, Govt. of India for providing financial support in the form of Inspire Faculty Fellowship. Narayana Reddy thanks to DST-SERB for a Start-Up Research Grant.

\section{References}

1. Knolker, H. J.; Reddy, K. R. Alkaloids Chem. Biol. 2008, 65, 1.

2. Knolker, H. J. Chem. Lett. 2009, 38, 8. http://dx.doi.org/10.1246/cl.2009.8

3. Thevissen, K.; Marchand, A.; Chaltin, P.; Meert, E. M. K.; Cammue, B. P. A. Curr. Med. Chem. 2009, 16, 2205. http://dx.doi.org/10.2174/092986709788612701

4. Okunade, A. L.; Elvin Lewis, M. P. F. In Novel Therapeutic Agents from Plants; Carpinella, M. C.; Rai, M.; Eds.; Science Publishers: Enfield: 2009; pp 405-452.

5. Salas, J. A.; Mendez, C. Curr. Opin. Chem. Biol. 2009, 13, 152. http://dx.doi.org/10.1016/j.cbpa.2009.02.003

6. Li, J.; Grimsdale, A. C. Chem. Soc. Rev. 2010, 39, 2399. http://dx.doi.org/10.1039/B915995A

7. Ates, M.; Sarac, A. S. Prog. Org. Coat. 2009, 66, 337. http://dx.doi.org/10.3390/s130607296

8. El Ashry, E. S. H.; Awad, L. F.; El Kilany, Y.; Ibrahim, E. I. Adv. Heterocycl. Chem. 2009, 98,1 http://dx.doi.org/10.1155/2013/818739

9. Yaqub, G.; Hussain, E. A.; Rehman, M. A.; Mateen, B. Asian J. Chem. 2009, 21, 2485.

10. Alexander, E. J.; Mooradian, A. U.S. Patent, 4, 001 270, 1976. Chem. Abstr. 1977, 87, 39275.

11. Mooradian, A. U.S. Patent, 3,959,309, 1976; Chem. Abstr. 1976, 85, 123759.

12. Mooradian, A. J. Med. Chem. 1977, 20, 487. http://dx.doi.org/10.1021/jm00214a005

13. Joyeeta, R.; Amit Kumar, J.; Dipakranjan, M. Tetrahedron 2012, 68, 6099. http://dx.doi.org/10.1016/j.tet.2012.05.007

14. Jean Francois, M.; Mario, L.; Dominique, A.; Alain S. Macromol Rapid Commun. 2005, 26,761 . http://dx.doi.org/10.1002/marc.200500096

15. Jean Paul L.; Rik Rani, K.; Subrata, G. Rev Chem Eng. 2013, 29, 413. http://dx.doi.org/10.1515/revce-2013-0023

16. Arndt, W. S.; Kethiri, R. R.; Hans, J. K. Chem. Rev. 2012, 112, 3193. http://dx.doi.org/10.1021/cr200447s 
17. Caruso, A.; Chimento, A.; ElKashef, H.; Lancelot, J. C.; Panno, A.; Pezzi, V.; Saturnino, C.; Sinicropi, M. S.; Sirianni, R.; Rault, S. J. Enzyme Inhib. Med. Chem. 2012, 27, 60.

18. Caruso, A.; Voisin, C. A. S.; Lancelot, J. C.; Sinicropi, M. S.; Garofalo, A.; Rault, S. Heterocycles 2007, 71, 2203.

19. Rodriguez, S. L.; Zaballos, G. E.; Gonzalez, R. E.; Testa, M. L.; Sepulveda, A. J.; Jones, R. A. Tetrahedron 2000, 56, 4511. http://dx.doi.org/10.1016/S0040-4020(00)00290-8

20. Hudkins, R. L.; Johnson, N. W.; Angeles, T. S.; Gessner, G. W.; Mallamo, J. P. J. Med. Chem. 2007, 50, 433. http://dx.doi.org/10.1021/jm051074u

21. Fousteris, M. A.; Papakyriakou, A.; Koutsourea, A.; Manioudaki, M.; Lampropoulou, E.; Papadimitriou, E.; Spyroulias, G. A.; Nikolaropoulos, S. S. J. Med. Chem. 2008, 51, 1048. http://dx.doi.org/10.1021/jm0700666

22. Chakrabarty, M.; Khasnobis, S. J. Indian Chem. Soc. 1997, 74, 917.

23. Pindur, U.; Lemster, T. Recent Res. Dev. Org. Bioorg. Chem. 1997, 1, 33.

24. Frohner, W.; Krahl, M. P.; Reddy, K. R.; Knolker, H. J. Heterocycles 2004, 63,2393 http://dx.doi.org/10.3987/REV-04-585

25. Agarwal, S.; Cammerer, S.; Filali, S.; Frohner, W.; Knoll, J.; Krahl, M. P.; Reddy, K. R.; Knolker, H. J. Curr. Org. Chem. 2005, 9, 1601. http://dx.doi.org/10.2174/138527205774370496

26. Pindur, U.; Kim, Y. S.; Mehrabani, F. Curr. Med. Chem. 1999, 6, 29.

27. Prudhomme, M. Eur. J. Med. Chem. 2003, 38, 123. http://dx.doi.org/10.1016/S0223-5234(03)00011-4

28. Prudhomme, M. Curr. Med. Chem. Anti-Cancer Agents 2004, 4, 509.

29. Appukkuttan, P.; Van der Eycken, E.; Dehaen, W. Synlett 2005, 127. http://dx.doi.org/10.1055/s-2004-836030

30. Ackermann, L.; Althammer, A. Angew. Chem. Int. Ed. 2007, 46, 1627. http://dx.doi.org/10.1002/anie.200603833

31. Klien, J. T.; Davis, L.; Oslen, G.; Wong, G.; Huger, F.; Smith, C.; Petko, W. J. Med. Chem. 1996, 39, 570 .

http://dx.doi.org/10.1021/jm9506433

32. Enyedy, I. J.; Ling, Y.; Nacro, K.; Tomita, Y.; Wu, X.; Cao, Y.; Guo, R.; Li, B.; Zhu, X.; Huang, Y.; Long, Y. Q.; Roller, P. P.; Yang, D.; Wang, S. J. Med. Chem. 2001, 44, 4313. http://dx.doi.org/10.1021/jm010016f

33. Block, M. H.; Boyer, S.; Brailsford, W.; Brittain, D. R.; Carroll, D.; Chapman, S.; Clarke, D. S.; Donald, C. S.; Foote, K. M.; Godfrey, L.; Ladner, A.; Marsham, P. R.; Masters, D. J.; Mee, C. D.; Donovan, M. R.; Pease, J. E.; Pickup, A. G.; Rayner, J. W.; Roberts, A.; Schofield, P.; Suleman, A.; Turnbull, A. V. J. Med. Chem. 2002, 45, 3509. http://dx.doi.org/10.1021/jm011125x 
34. Hiscock, J. R.; Caltagirone, C.; Light, M. E.; Hursthouse, M. B.; Gale, P. A. Org. Biomol. Chem. 2009, 7, 1781. http://dx.doi.org/10.1039/B900178F

35. Hirschfeld, S. US Patent 4514508, 1985.

36. Otieno, M. A.; Baggs, R. B.; Hayes J. D.; Anders, M. W. Drug Metab. Dispos. 1997, 25, 12.

37. Haq, M. R.; Kalatzis, V.; Gubler, M. C.; Town, M. M.; Antignac, C.; Vant Hoff, W. G.; Woolf, A. S. J. Am. Soc. Nephrol. 2002, 13, 2046.

38. Comas, T. C.; Tai, T.; Kimmel, D.; Scheithauer, B. W.; Burger, P. C.; Pearl, D. K.; Jewell, S. D.; Yates, A. J. Neuro-oncology 1999, 1, 261. http://dx.doi.org/10.1093/neuonc/1.4.261

39. Peciuraite, V.; Vaitkeviciene, V.; Grigalevicius, S.; Grazulevicius J. V.; Jankauskas V. Monatsh. Chem. 2006, 137, 1053.

40. Puodziukynaite, E.; Burbulis, E.; Grazulevicius, J. V.; Getautis V.; Jankauskas J. Synthetic Metals 2008, 158, 993. http://dx.doi.org/10.1016/j.synthmet.2008.06.030

41. Mishra, A. K.; Jacob J.; Mullen, K. Dyes Pigments 2007, 75. http://dx.doi.org/10.1016/j.dyepig.2006.05.025

42. Gibson, H. W.; Olin G. R.; Pochan, J. M. J. Chem. Soc. Perkin Trans. II 1981, 1267. http://dx.doi.org/10.1039/P29810001274

43. Grigoras, M.; Antonoaia, N. C. Euro. Poly. J. 2005, 41, 1079. http://dx.doi.org/10.1016/j.eurpolymj.2004.11.019

44. Diego, F.; Abbiati, G.; Dellacqua, M.; Rossi, E. Tetrahedron 2011, 67, 6833.

45. Isravel A.; Karnam J. R.; Prasad. Z. Naturforsch 2004, 59b, 1054.

46. Kefuman, F.; Zweffef, F. Helv. Chim. Acta 1928, 11, I213.

47. Lindemann, H. Ber. Dtsch. Chem. Ges. 1924, 57, 555. http://dx.doi.org/10.1002/cber.19240570333

48. Lindemann, H.; Werther, F. Ber. Dtsch. Chem. Ges. 1924, 57, 1316. http://dx.doi.org/10.1002/cber.19240570816

49. Campbell, N.; Barclay, B. M. Chem. Rev. 1947, 40, 359. http://dx.doi.org/10.1021/cr60127a001

50. Bergman, J.; Carisson, R. Tetrahedron Lett. 1978, 4051. http://dx.doi.org/10.1016/S0040-4039(01)95137-8

51. Chmielewski, M. J.; Charon, M.; Jurczak, J. Org. Lett. 2004, 6, 3501. http://dx.doi.org/10.1021/o1048661e

52. Akermark, B.; Eberson, L.; Jonsson, E.; Pettersson, E. J. Org. Chem. 1975, 40, 1365. http://dx.doi.org/10.1021/jo00897a048

53. Barluenga, J.; Tomas, M.; Rubio, E.; Lopez-Pelegrin, J. A.; Garcia-Granda, S.; Priede, M. P. J. Am. Chem. Soc. 1999, 121, 3065. http://dx.doi.org/10.1021/ja983692o 
54. Kyziol, J. B.; Lyzniak, A. Tetrahedron 1980, 36, 3017. http://dx.doi.org/10.1016/0040-4020(80)88027-6

55. Stover, J. S.; Shi, J.; Jin, W.; Vogt, P. K.; Boger, D. L. J. Am. Chem. Soc. 2009, 131, 3342. http://dx.doi.org/10.1021/ja809083d

56. Mudadu, M. S.; Singh, A. N.; Thummel, R. P. J. Org. Chem. 2008, 73, 6513. http://dx.doi.org/10.1021/jo801132w

57. Chabane, H.; Lamazzi, C.; Thiery, V.; Guillaumet, G.; Besson, T. Tetrahedron Lett. 2002, 43, 2483. http://dx.doi.org/10.1016/S0040-4039(02)00353-2

58. Estrada, L. A.; Neckers, D. C. Org. Lett. 2011, 13, 3304. http://dx.doi.org/10.1021/ol200354t

59. Lee, H. Y.; Chen, G. S.; Chen, C. S.; Chern, J. W. J. Heterocycl. Chem. 2010, 47, 454. http://dx.doi.org/10.1002/jhet.319

60. Knolker, H. J.; Reddy, K. R. In The Alkaloids; Cordell, G. A., Ed.; Academic: Amsterdam, 2008; Vol. 65, pp 1-430.

61. Gribble, G. W. In The Alkaloids; Brossi, A., Ed.; Academic: San Diego, CA, 1990; pp 239352.

62. Molina, P.; Fresneda, P. M.; Almendros, P. Tetrahedron 1993, 49, 1223. http://dx.doi.org/10.1016/S0040-4020(01)85813-0

63. Kirsch, G. H. Curr. Org. Chem. 2001, 5, 507. http://dx.doi.org/10.2174/1385272013375409

64. Bergman, J.; Janosik, T.; Wahlstrom, N. Adv. Heterocycl. Chem. 2001, 80, 1. http;//dx.doi.org/10.1016/S0065-2725(01)80012-X

65. Knolker, H. J.; Reddy, K. R. Chem. Rev. 2002, 102, 4303.

66. Bellina, F.; Rossi, R. Tetrahedron 2006, 62, 7213. http://dx.doi.org/10.1016/j.tet.2006.05.024

67. Sanchez, C.; Mendez, C.; Salas, J. A. Nat. Prod. Rep. 2006, 23, 1007. http://dx.doi.org/10.1039/B601930G

68. Tsuchimoto, T.; Matsubayashi, H.; Kaneko, M.; Nagase, Y.; Miyamura, T.; Shirakawa, E. J. Am. Chem. Soc. 2008, 130, 15823. http://dx.doi.org/10.1021/ja803954e

69. Perche, J. C.; Saint-Ruf, G.; J. Heterocyclic Chem. 1974, 11, 93. http://dx.doi.org/10.1002/jhet.5570110123

70. Romeiro, G. A.; Khan, M. A. Ferreira, V. F. J. Braz. Chem. Soc. 1991, 2, 1.

71. Hedin, V. M.; Tabka, T.; Poulain, L.; Godard, T.; Lachevrel, M.; Saturnino, C.; Lancelot, J. C.; Le Talaer, J. Y.; Gauduchon, P. Anti-Cancer Drug Design 2000, 15, 109.

72. Fidesser, E.; Haider, N.; Jabra, R. Arkivoc, 2001, (v), 133.

73. Juret, P.; Tanguy, A.; Girard, A.; Le Talaer, J. Y.; Abbatucci, J. S.; Dat Xuong, N.; Le Pecq, J. B.; Paoletti, C. Eur. J. Cancer 1978, 14, 205. 
74. Auclair, C.; Voisin, E.; Banoun, H.; Paoletti, C.; Bernadou, J.; Meunier, B. J. Med. Chem. 1984, 27, 1161.

75. http://dx.doi.org/10.1021/jm00375a013

76. Stiborova, M.; Breuer, A.; Aimova, D.; Stiborova-Rupertova, M.; Wiessler, M.; Frei, E. Int. J. Cancer. 2003, 107, 885. http://dx.doi.org/10.1002/ijc.11511

77. Viji, M.; Nagarajan, R. Synthesis 2012, 44, 253. http://dx.doi.org/10.1055/s-0031-1289967

78. Sapijanskaite, B.; Mickevicius, V.; Mikulskiene, G. Molecules 2006, 11, 72. http://dx.doi.org/10.3390/11010072

79. Kulka, M.; Manske, H. F. J. Org. Chem. 1952, 17, 1501. http://dx.doi.org/10.1021/jo50011a016

80. Nagarajan, R.; Jella, R. R. Synlett 2011, 4, 529. http://dx.doi.org/10.1055/s-0030-1259530

81. Stiborova, M.; Bieler, C. A.; Wiessler, M.; Frei, E. Biochem. Pharmacol. 2001, 62,

82. $1675-1684$. http://dx.doi.org/10.1016/S0006-2952(01)00806-1

83. Stiborova, M.; Breuer, A.; Aimova, D.; Stiborová-Rupertova, M.; Wiessler, M.;

84. Frei, E. Int. J. Cancer 2003, 107, 885-890. http://dx.doi.org/10.1002/ijc.11511

85. Auclair, C. Arch Biochem. Biophys. 1987, 259, 1-14.

86. Gaddam, V.; Nagarajan, R. Tetrahedron Lett. 2009, 50, 1243. http://dx.doi.org/10.1016/j.tetlet.2009.01.020

87. Wang, X.; Zhou, J.; Yin, M.; Yang, K.; Tu, S. J. Heterocyclic.Chem. 2010, 47, 873. http://dx.doi.org/10.1002/jhet.404

88. Gaddam, V.; Nagarajan, R. Org. Lett. 2008, 10, 1975. http://dx.doi.org/10.1021/o1800497u

89. Gaddam, V.; Ramesh, S.; Nagarajan, R. Tetrahedron 2010, 66, 4218. http://dx.doi.org/10.1016/j.tet.2010.03.095

90. Li, X.; Mao, Z.; Wang, Y.; Chen, W.; Lin, X. Tetrahedron 2011, 67, 3858. http://dx.doi.org/10.1016/j.tet.2011.03.087

91. Besson, T.; Guillaumet, G.; Lamazzi, C.; Rees, C. W.; Thiery, V. J. Chem. Soc., Perkin Trans. 1998, 1, 4057. http://dx.doi.org/10.1039/A807759B

92. Chabane, H.; Lamazzi, C.; Thiery, V.; Guillaumet, G.; Besson, T. Tetrahedron Lett. 2002, $43,2483$.

http://dx.doi.org/10.1016/S0040-4039(02)00353-2

93. Chakrabarty, M.; Ghosh, N.; Harigaya, Y. Tetrahedron Lett. 2004, 45, 4955. http://dx.doi.org/10.1016/j.tetlet.2004.04.129 
94. Debray, J.; Zeghida, W.; Baldeyrou, B.; Mahieu, C.; Lansiaux, A.; Demeunynck, M.

Bioorg. Med. Chem. Lett. 2010, 20, 4244.

http://dx.doi.org/10.1016/j.bmcl.2010.05.028

95. Caruso, A.; Sinicropi, M. S.; Lancelot, J.; El-Kashef, H.; Saturnino, C.; Ballandonne, G. A. C.; Lesnard, A.; Cresteil, T.; Dallemagne, P.; Rault, S. Bioorg. Med. Chem. Lett. 2014, 24, 467.

http://dx.doi.org/10.1016/j.bmcl.2013.12.047

96. Akuegedu, R.; Rossignol, E.; Azzaro, S.; Knapp, S.; Filippakopoulos, P.; Bullock, A. N.; Bain, J.; Cohen, P.; Prudhomme, M.; Anizon, F.; Moreau, P. J. Med. Chem. 2009, 52,6369. http://dx.doi.org/10.1021/jm901018f

97. Hugon, B.; Anizon, F.; Bailly, C.; Golsteyn, R. M.; Pierre,A.; Leonce, S.; Hickman, J.;

Pfeiffer, B.; Prudhomme, M. Bioorg. Med. Chem. 2007, 15, 5965.

http://dx.doi.org/10.1016/j.bmc.2007.05.073

98. Knolker, H. J.; Reddy, K. R. In The Alkaloids; Cordell, G. A., Ed.; Academic: Amsterdam, 2008, 65, 1-430

99. Viji, M.; Nagarajan, R. Tetrahedron 2012, 68, 2453.

http://dx.doi.org/10.1016/j.tet.2012.01.070

100. Mayavan, V.; Nagarajan, R. RSC Advances 2012, 2, 10544. http://dx.doi.org/10.1039/C2RA21735J

101. Meesala, R.; Nagarajan, R. Tetrahedron 2009, 65, 6050. http://dx.doi.org/10.1016/j.tet.2009.05.061

102. Roseman, K.; Gould, M.; Linfield, M.; Edwards, B. J. Med. Chem. 1970, 13, 230.

103. http://dx.doi.org/10.1021/jm00296a015

104. Yamuna, E.; Zeller, M.; Rajendra Prasad, K. J. Tetrahedron Lett. 2012, 53, 1514. http://dx.doi.org/10.1016/j.tetlet.2012.01.057

105. Wang, X.; Yin, M.; Wang, W.; Tu, S. Eur. J. Org. Chem. 2012, 4811. http://dx.doi.org/10.1002/ejoc.201200551

106. Ramu, M.; Nagarajan, R. Synlett, 2010, 18, 2808. http://dx.doi.org/10.1055/s-0030-1258818

107. Yang, J.; Ahu, A.; Li, Z. J. Heterocyclic Chem. 2012, 49, 1458. http://dx.doi.org/10.1002/jhet.1047

108. Shi, F.; Zeng, X.; Cao, X.; Zhang, S.; Jiang, B.; Zheng, W.; Tu, S. Bioorg. Med. Chem. Lett. 2012, 22, 743. http://dx.doi.org/10.1016/j.bmcl.2011.09.081

109. Yamuna, E.; Zeller, M.; Rajendra Prasad, K. J. Tetrahedron Lett. 2011, 52, 6805. http://dx.doi.org/10.1016/j.tetlet.2011.10.044

110. Ramesh, S.; Nagarajan, R. Synthesis 2011, $20,3307$. http://dx.doi.org/10.1055/s-0030-1260135

111. Reddy. S.; Rao, V. K.; Krishna, B. S.; Reddy, C. S.; Rao, P. V.; Raju, C. N. Phosphorus, Sulphur and Silicon 2011, 186, 1411. 
112. Kona, S.; Venkata N. R.; Suresh Ravi, C. R.; Ramu Sridhar, R.; Chakravarty, M. Der Chemica Sinica 2012, 3, 548.

\section{Authors' Biographies}

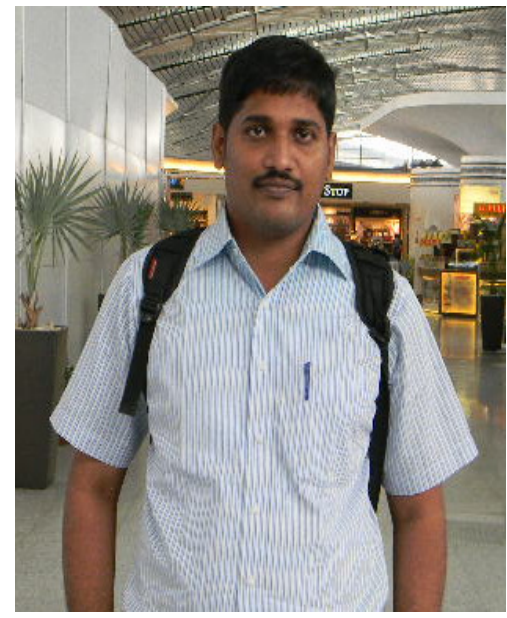

Dr. Narayana Reddy was born in India. He received his MSc degree in organic chemistry from Sri Venkateswara University, India. He carried out his doctoral research at Indian Institute of Chemical Technology and received his PhD degree from Andhra University in 2011. Research Scientist, Biophore India Pvt Ltd (2009-2010), Postdoctoral fellow, Sejong University, South Korea (2010-2011), Research Scientist, Piramal Healthcare Ltd (2011-2013). He is currently an Assistant Professor of Chemistry at Gitam University, School of Technology, Hyderabad, India.

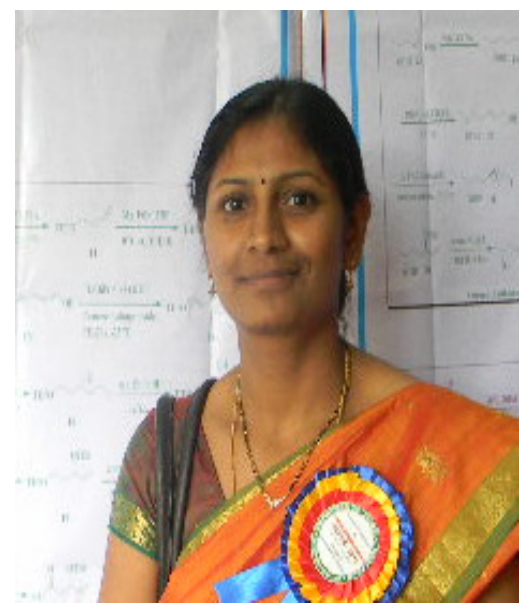

Dr. Padmaja was born in India. She received her Msc. degree in organic chemistry from Osmania University, India. She carried out doctoral research at Indian Institute of Chemical Technology and received her PhD degree from Osmania University in 2012. She is currently working as DST-Inspire faculty at Jawaharlal Nehru Technological University, Hyderabad, India. 